\title{
Stable isotope compositions of speleothems from the last interglacial - Spatial patterns of climate fluctuations in Europe
}

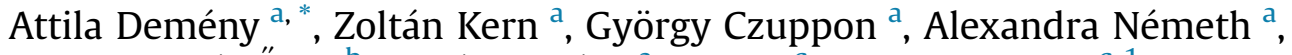 \\ Szabolcs Leél-Őssy ${ }^{\mathrm{b}}$, Zoltán Siklósy ${ }^{\mathrm{a}}$, Ke Lin ${ }^{\mathrm{c}}$, Hsun-Ming Hu ${ }^{\mathrm{c}, 1}$, Chuan-Chou Shen ${ }^{\mathrm{c}}$, \\ Torsten W. Vennemann ${ }^{\mathrm{d}}$, László Haszpra ${ }^{\mathrm{e}, \mathrm{f}}$ \\ ${ }^{a}$ Institute for Geological and Geochemical Research, Research Centre for Astronomy and Earth Sciences, Hungarian Academy of Sciences, Budapest, Budaörsi \\ út 45, H-1112, Hungary \\ ${ }^{\mathrm{b}}$ Department of Physical and Applied Geology, Eötvös University, Budapest, Pázmány Péter sétány 1/C, H-1117, Hungary \\ ${ }^{\mathrm{c}}$ High-Precision Mass Spectrometry and Environment Change Laboratory (HISPEC), Department of Geosciences, National Taiwan University, Taipei 10617, \\ Taiwan \\ ${ }^{\mathrm{d}}$ University of Lausanne, Institute of Earth Surface Dynamics, CH-1015 Lausanne, Switzerland \\ e Hungarian Meteorological Service, Budapest, Kitaibel Pál u. 1, H-1024, Hungary \\ ${ }^{\mathrm{f}}$ Geodetic and Geophysical Institute, Research Centre for Astronomy and Earth Sciences, Hungarian Academy of Sciences, Sopron, Csatkai E. u. 6-8, H-9400, \\ Hungary
}

\section{A R T I C L E I N F O}

\section{Article history:}

Received 21 December 2016

Received in revised form

10 February 2017

Accepted 10 February 2017

\section{Keywords:}

Last interglacial

Speleothems

Europe

Stable isotope compositions

Fluid inclusions

\begin{abstract}
A B S T R A C T
Studies on the last interglacial (LIG) can provide information on how our environment behaved in a period of slightly higher global temperatures at about $125 \pm 4 \mathrm{ka}$, even if it is not the best analogue for the Holocene. The available LIG climate proxy records are usually better preserved and can be studied at a higher resolution than those of the preceding interglacials, allowing detailed comparisons. This paper presents complex stable hydrogen, carbon and oxygen isotope records obtained for carbonate $\left(\delta^{13} \mathrm{C}\right.$ and $\left.\delta^{18} \mathrm{O}_{\text {carb }}\right)$ and fluid inclusion hosted water $\left(\delta \mathrm{D}\right.$ and $\left.\delta^{18} \mathrm{O}_{\mathrm{w}}\right)$ of a stalagmite from the Baradla Cave system in Central Europe that covers most of the LIG, as proven by U-Th dates. Comparing its $\mathrm{C}$ and $\mathrm{O}$ isotope data with records reported for other speleothem (cave-hosted carbonate) deposits from Europe revealed the complex behavior of these climate proxies, with a concerted relative increase in ${ }^{18} \mathrm{O}$ of carbonates from 128 to $120 \mathrm{ka}$ and synchronized shifts in the opposite direction after $119 \mathrm{ka}$. The hydrogen isotope analyses of inclusion-hosted water extracted from the BAR-II stalagmite also correspond to the regional climate proxy records, with meaningful deviations from global temperature trends. Beside following the general paleotemperature pattern from the climate optimum (high $\delta \mathrm{D}$ values up to $-64 \%$ around $120 \mathrm{ka}$ ) to the subsequent cooling starting at about $119 \mathrm{ka}$ (low $\delta \mathrm{D}$ values down to $-90 \%$ at about $109 \mathrm{ka}$ ), a period between 126.5 and 123 ka with low $\delta \mathrm{D}$ values (down to $-81 \%$ ) is detected in the BAR-II stalagmite. Although the isotope shifts are muted in the C-O isotope data of carbonate due to competitive fractionation processes, the $\delta^{13} \mathrm{C}$ data show a positive relationship with the $\delta \mathrm{D}$ pattern, indicating humidity - and possibly temperature - variations. The periods with low $\delta \mathrm{D}$ values fit well to temperature and humidity changes inferred from proxy records from western Europe to the eastern Mediterranean. Spatial distributions of these variables show, that at about $125 \pm 2$ ka the Mediterranean region was characterized by warm, humid conditions and enhanced seasonality with elevated winter precipitation. The combined interpretation of stable isotope data revealed that the Alpine and Mediterranean regions behaved differently during Greenland Stadial 26 (GS26, 119 to $116.2 \mathrm{ka}$ ). While the Alpine records fluctuated in close agreement with the Central Greenland ice core $\delta^{18} \mathrm{O}$ data, the BAR-II stalagmite show a positive $\delta^{18} \mathrm{O}_{\text {carb }}$ anomaly. The Baradla data indicate enhanced aridity and seasonality for a part of GS26, with the relative dominance of summer
\end{abstract}

\footnotetext{
* Corresponding author.

E-mail addresses: demeny@geochem.hu (A. Demény), zoltan.kern@gmail.com (Z. Kern), czuppon@geochem.hu (G. Czuppon), nemethalexandra89@gmail.com

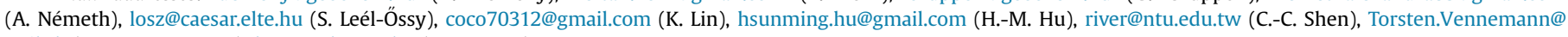
unil.ch (T.W. Vennemann), haszpra.l@met.hu (L. Haszpra).

${ }^{1}$ Present address: Earth Observatory of Singapore (EOS), Nanyang Technological University, 50 Nanyang Avenue, Block N2-01a-15, Singapore 639798, Singapore.
} 
precipitation and Mediterranean moisture contribution. Following the GS26 event, the effect of longterm global cooling becomes dominant in the Baradla isotope records and leads to glacial inception at about 109 ka.

(C) 2017 Elsevier Ltd. All rights reserved.

\section{Introduction}

In the last 5 million years Earth's climate has experienced substantial cooling, leading to an ice age characterized by the repeated expansions of extensive ice sheets (Lisiecki and Raymo, 2005). Stable isotope compositions of deep sea drilling cores and ice cores from the Antarctic continent convincingly indicate that the period of the last $\sim 1$ million years was dominated by cold (glacial) periods cyclically interrupted by warm periods, called interglacials (EPICA community members, 2004; Lisiecki and Raymo, 2005). At present we are living in an interglacial that provides a comfortably warm and humid environment for the human society. The future of our society depends largely on the evolution of the natural environment, hence the understanding of how the present interglacial will change and how natural processes and anthropogenic influences can contribute to the temperature and humidity changes is increasingly important. Beside global climate models that forecast meteorological changes from the present to the near future, paleoproxy records of sedimentary formations (marine sediments, lake deposits, speleothems, etc.) formed during past interglacial periods can provide important data on how temperature and precipitation conditions evolved on decadal to millennial time scales. The best natural analogue for the present interglacial would be the warm period around 400 ka before present, as the orbital parameters that determine insolation were similar to the present day situation (Loutre and Berger, 2003). Unfortunately, as we go back in time, suitable paleoproxy records become less and less frequent due to their decreasing availability and subsequent alterations. This is especially true for speleothems, as the formations of earlier interglacials are generally covered by younger deposits and the large stalagmites are usually strictly protected, prohibiting appropriate sampling (i.e., microdrilling along the growth axis on a polished cross section). A rare exception is the compiled database of Chinese speleothems that cover the last $640 \mathrm{ka}$ and whose composite stable oxygen isotope record could be compared with solar insolation values and orbital parameters (Cheng et al., 2016).

Speleothems are valuable in paleoclimate studies for a number of reasons (see the comprehensive review by Fairchild and Baker, 2012): i) they can be precisely dated using the U-Th series method providing a solid base for investigations of temporal evolution of paleoclimate proxies; ii) speleothems are formed in protected and relatively stable cave environments and hence are not exposed to late-stage alterations (like in case of sedimentary diagenesis that is generally induced by significant temperature changes coupled with influx of exotic fluids); iii) speleothems can be studied by geochemical methods that provide valuable environmental proxies such as stable isotope and trace element compositions. Compared to earlier periods, stalagmites from the last interglacial (LIG) are rather frequent and can be studied in sufficient numbers (Govin et al., 2015). Stable C and O isotope records, for instance, from European caves' carbonate deposits are available from Belgium (Vansteenberge et al., 2016), the Alps (Austria; Meyer et al., 2008; Boch et al., 2011; Moseley et al., 2015), the Massif Central (France; Couchoud et al., 2009), and the Apuane Alps (Italy; Drysdale et al., 2005, 2007). These records have been dated by the U-Th series dating method providing numerical ages, making them valuable for paleoclimate studies on the LIG, although their geochemical compositions have not been evaluated in detail as yet (Govin et al., 2015). Besides conventional carbonate $C$ and O isotope analyses, $\mathrm{H}$ and $\mathrm{O}$ isotope values of water trapped in the fluid inclusions of stalagmites have gained increasing importance in recent years as technical developments improved sampling resolution, analytical precision and throughput (Vonhof et al., 2006; van Breukelen et al., 2008; Dublyansky and Spötl, 2009; Griffiths et al., 2010; Wainer et al., 2011; Rowe et al., 2012; Arienzo et al., 2013; Ayalon et al., 2013; Affolter et al., 2014). The main advantage of fluid inclusion analyses is that - in contrast to $\mathrm{C}$ and $\mathrm{O}$ isotope ratios of the precipitating carbonate that depend on a large number of factors (see Fairchild and Baker, 2012) - H and O isotope compositions of the water are not fractionated during entrapment, and hence can directly reflect the composition of dripwater (Harmon and Schwarcz, 1981; Yonge, 1982). Although, following deposition, the oxygen isotope composition of the trapped water can change in the course of diagenetic alteration (Demény et al., 2016a), the hydrogen isotope composition remains intact during and after the entrapment. In this study we present the carbonate $C$ and $\mathrm{O}$ isotope compositions as well as fluid inclusion $\mathrm{H}$ and $\mathrm{O}$ isotope values of a stalagmite from the Baradla Cave (NE Hungary) that were used to detect paleohydrological changes in the last interglacial. These records were compared with paleoproxy data obtained from Western and Central Europe and the Mediterranean region in order to reveal spatial temperature and humidity changes in the course of the LIG.

\section{Cave site and stalagmites}

The Baradla Cave is situated in north-east Hungary ( $N 48^{\circ} 28^{\prime}$ $\mathrm{E} 20^{\circ} 30^{\prime}$ ) at the Hungarian-Slovakian border, beneath a forested area with a mean elevation of 300-450 m a.s.l. The cave system was formed in lagoon facies of the Wetterstein Limestone of the Triassic (Ladinian) age and is characterized by almost horizontal passages. The area is under the influence of European cyclone tracks with the most important cyclogenesis centers in the Icelandic and the Western Mediterranean regions (Bartholy et al., 2006, 2009). Cyclones starting-up near these regions transport marine moisture to Hungary (Bottyán et al., 2013) by the induced frontal systems. Most Icelandic cyclones arrive in winter, but approximately 30 cyclones derive from the Mediterranean area, most frequently in spring (Kelemen et al., 2015). Significant weather influences could also come from the East (Bartholy et al., 2006). However, this weather pattern brings cold/dry air into the region, so precipitation is typically not accompanied with these macrocirculation situations. The most characteristic season and situation when such influences can be prevailing is winter, when cold polar/continental air masses intrude to the region. Monthly averages of precipitation amount, temperature and potential evapotranspiration data were extracted from the Carpatclim dataset (Szalai et al., 2013) that indicate that infiltration may occur in the period of November to April, while evapotranspiration exceeds precipitation in the warm months (Demény et al., 2016b).

On the basis of combined evaluation of cave monitoring data, as well as textural, stable isotope and trace element analyses of four 
actively growing stalagmites and their comparison with meteorological data, Demény et al. (2016b) determined that carbon isotope compositions of compact, slowly growing stalagmites of the Baradla Cave reflect variations in winter precipitation amount, while their oxygen isotope composition can be considered as a proxy for winter temperature. Although these relationships were calibrated for the current interglacial conditions, they can provide a basis for the interpretation of stable isotope compositions of the stalagmite formed during the last interglacial.

The collection site of the stalagmite studied in this paper is about $1 \mathrm{~km}$ away from the nearest entrance (Fig. 1) and under about $150 \mathrm{~m}$ of host rock cover. Cave conditions were characterized by spot measurements conducted during water sampling (Demény et al., 2016b). Cave temperature was $9.7 \pm 0.5{ }^{\circ} \mathrm{C}, \mathrm{CO}_{2}$ content was $3500 \pm 1100 \mathrm{ppm}$, pH was $7.9 \pm 0.3(\mathrm{n}=14)$. Dripwater compositions were fairly constant in the entire cave $(\delta \mathrm{D}=-66 \pm 1.5 \%$, $\delta^{18} \mathrm{O}=-9.5 \pm 0.2 \%$, $\left.\mathrm{n}=27\right)$. The stalagmite studied in this paper (BAR-II) is actually a double one, with two columns, 34 and $36 \mathrm{~cm}$ long (BAR-II\#L and BARII\#B, respectively). The internal textures of the cut and polished surfaces of the two separate columns are very similar, with clear hiata (Fig. 1). The stalagmites are composed of dense, well-crystallized calcite. Four major textural types characterize both stalagmite columns: the formation starts with a finely laminated texture in which the lamination is expressed by whitish, inclusion-rich layers (\#1). This is followed by white, cloudy, inclusion-rich texture (\#2), then translucent calcite with fine lamination (\#3) and texture \#2 again. The white, cloudy texture becomes gradually pale and lamination appears (\#4) that turns into translucent, finely laminated calcite (\#3). Hiatus \#1 (see Fig. 1) closes this sequence as a $\sim 1 \mathrm{~mm}$ thick white (yellowish at the sides) layer. Stalagmite formation continues with translucent calcite, but this part is not investigated in this paper. Both columns were dated by $U$-Th series method. High-resolution carbon and oxygen isotope analyses were conducted on the BAR-II\#B column, BAR-II\#L was used for a replication test. Both columns were analysed by means of hydrogen and oxygen isotope measurements of fluid inclusionhosted water.

\section{Analytical methods}

Altogether 23 U-Th dates were obtained for the two columns of the BAR-II double stalagmite (Fig. 1), placed either at hiata or distributed evenly along the stalagmite's axis. The U-Th age determinations were conducted at the Department of Geosciences, National Taiwan University using standard procedure (Shen et al., 2002, 2003). The BAR-IIB stalagmite column was analysed in two analytical runs in 2007 and 2015, whereas the analyses of the BARIIL column was conducted only during the 2015 run. Sample chips $(0.1-0.2 \mathrm{~g})$ were dissolved in $\mathrm{HNO}_{3}$, spiked with a mixed ${ }^{229} \mathrm{Th}^{233} \mathrm{U}-{ }^{236} \mathrm{U}$ tracer, refluxed and evaporated. $U$ and Th were coprecipitated with an Fe-carrier, then separated to form a clean $U$ fraction and a clean Th fraction using an anion exchange resin (Shen et al., 2003). The isotopic compositions of $U$ and $T h$ in the solutions were measured by a Thermo Electron NEPTUNE multi-collector inductively coupled plasma mass spectrometer (MC-ICP-MS) (Shen et al., 2012). The obtained ages are given as year BP ("Before Present", i.e., before the analyses' dates). The results of the two analytical runs in 2007 and 2015 showed excellent agreement (see Supplementary Table 1). The estimated uncertainty of individual dates range from 683 to 1288 years (with an average of 864 years). Age depth models for the stalagmite columns BAR-II\#B and BARII\#L (Fig. 2) were established using the StalAge algorithm (Scholz and Hoffmann, 2011). The Stalage model fit all the age dates of the BAR-II\#B column well, while it deviates from the youngest age date in case of the BAR-II\#L column. This calculation problem has also been detected by Mudelsee et al. (2012) for a case when the youngest date deviates significantly from the age-depth relationship for other samples from the same stalagmite. Since only the youngest part and only one age date point is influenced in the BARII\#L column that served as a replication test for the BAR-II\#B

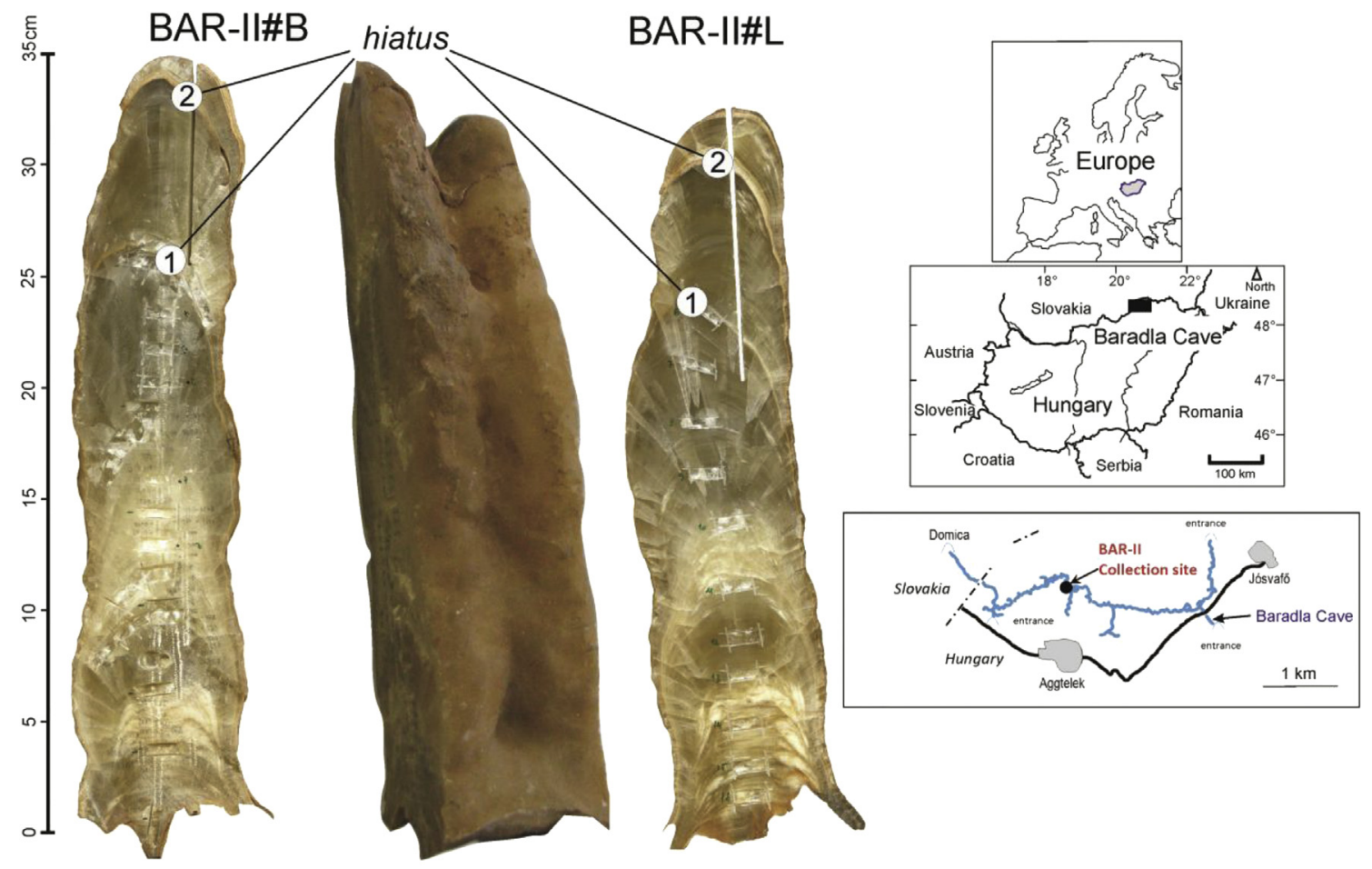

Fig. 1. Cave site locations and pictures of stalagmites collected from the Baradla Cave, NE Hungary. Numbers in circles within the BAR-II\#B and L stalagmites denote hiatuses. 


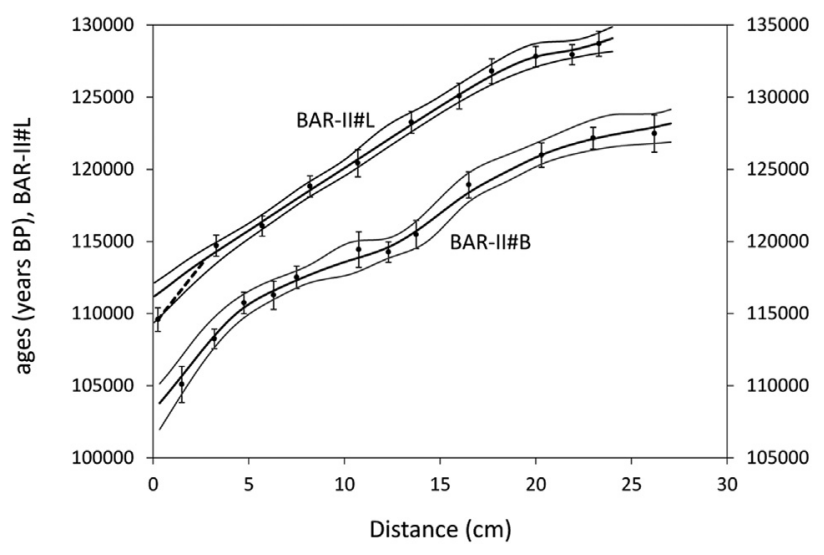

Fig. 2. Age-depth relationships for the BAR-II\#L and BAR-II\#B stalagmite columns. UTh ages and their errors are listed in Supplementary Table 1. Model curves and their uncertainties were established using the StalAge algorithm of Scholz and Hoffmann (2011), except the youngest part of the BAR-II\#L stalagmite column, where a linear age-depth model was applied (marked by dashed line).

column analysed at higher resolution, StalAge estimates have been replaced by a simple linear interpolated age-depth relationship above the last two age dates of BAR-II\#L.

Stable carbon and oxygen isotope compositions were determined on calcite powder drilled at a spatial resolution of about $5 \mathrm{~mm}$ for a preliminary investigation, then at $<1 \mathrm{~mm}$ resolution for a detailed study using the continuous flow isotope ratio mass spectrometric method (Spötl and Vennemann, 2003). The lowresolution analyses of the BAR-II\#L column were conducted at the University of Lausanne, the higher resolution measurements on the BAR-II\#B column were made at the Institute for Geological and Geochemical Research (IGGR), Budapest. Isotopic compositions are expressed as $\delta^{13} \mathrm{C}$ and $\delta^{18} \mathrm{O}$ in \%o relative to $\mathrm{V}$-PDB, with a precision better than $\pm 0.1 \%$ o (based on replicate analyses of samples and standards). Stable hydrogen and oxygen isotope compositions were determined in the water extracted from fluid inclusions at the IGGR, Budapest, using the laser spectrometric method described by Czuppon et al. (2014) and Demény et al. (2016a). The reproducibilities of the $\delta \mathrm{D}$ and $\delta^{18} \mathrm{O}$ values are better than \pm 2 and $0.5 \%$, respectively. As hydrogen and carbon isotope compositions are reported only for water and carbonate, respectively, $\delta \mathrm{D}$ and $\delta^{13} \mathrm{C}$ will not be distinguished for water or carbonate, whereas $\delta^{18} \mathrm{O}$ will be expressed as $\delta^{18} \mathrm{O}_{\text {carb }}$ or $\delta^{18} \mathrm{O}_{\mathrm{w}}$ when carbonate or water is not explicitly stated.

\section{Results}

The two columns of the BAR-II stalagmite were dated by U-Th method from the bases to a major hiatus (hiatus 1 marked in Fig. 1), starting from $127.5 \pm 1.3 \mathrm{ka}$ (BAR-II\#B) and $128.7 \pm 0.9 \mathrm{ka}$ (BAR$\mathrm{II} \# \mathrm{~L})$ and ending at $110.1 \pm 1.3 \mathrm{ka}(\mathrm{BAR}-\mathrm{II} \mathrm{AB})$ and $109.6 \pm 0.9 \mathrm{ka}$ (BAR-II\#L) (see Supplementary Table 1). The separate age-depth model curves are quite similar (Fig. 2) and show that the stalagmite fulfils the suitability criteria of sufficiently fast and stable growth rate to achieve appropriate resolution (Genty et al., 2013; Govin et al., 2015).

Hendy test analyses (Hendy, 1971) were conducted for six laminae of the BAR-II\#B stalagmite (Supplementary Table 2, Fig. 3), although it should be noted that sampling of annual laminae at a growth rate of $\sim 0.01 \mathrm{~mm} /$ year was not possible, and the sampling of collected layers spans $50-100$ years. This spatial resolution issue was one of the reasons why Dorale and Liu (2009) criticized the use of the Hendy test and suggested the Replication Test instead.

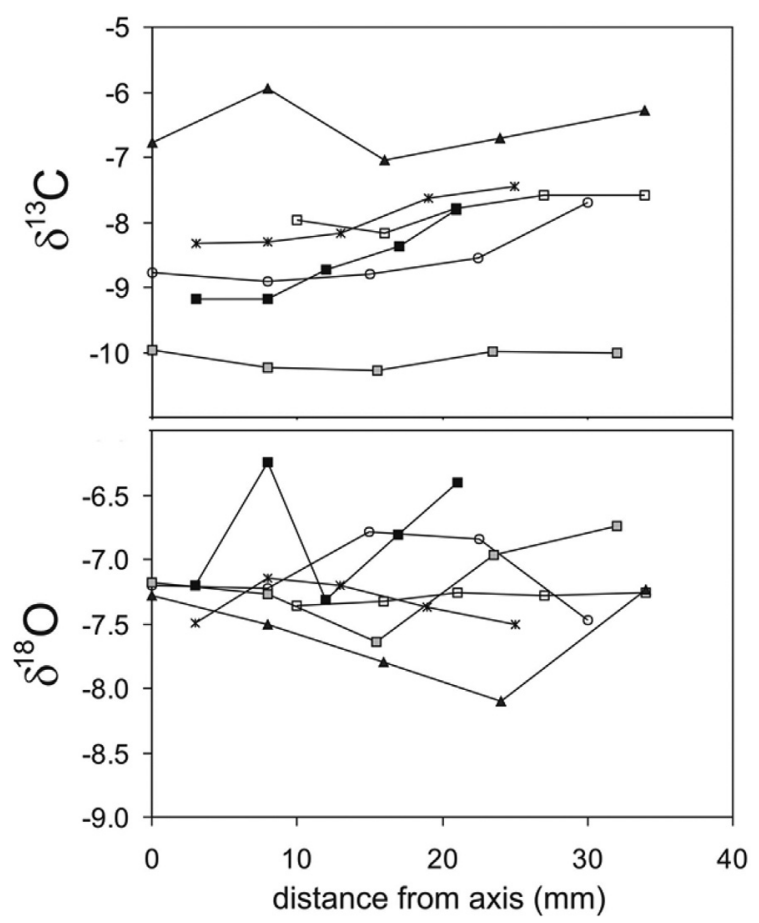

Fig. 3. Stable carbon and oxygen isotope compositions (in\%, relative to V-PDB) of the BAR-II\#B stalagmite along six laminae (Hendy test, Hendy, 1971).

Nevertheless, we should note that the sampled layers showed no positive $\delta^{18} \mathrm{O}-\delta^{13} \mathrm{C}$ correlation, only the $\delta^{13} \mathrm{C}$ values were shifted in the positive direction by $\sim 0.7 \%$ (average shift for the six layers).

Stable carbon and oxygen isotope compositions obtained for the stalagmite columns are listed in Supplementary Table 3. The highresolution $\delta^{13} \mathrm{C}$ and $\delta^{18} \mathrm{O}_{\text {carb }}$ values gathered for the BAR-II\#B column at the IGGR, Budapest match the isotopic compositions obtained for the BAR-II\#L column at the University of Lausanne (Fig. 4) that gives credit to the compositions by means of laboratory-related data precision and stalagmite record replication. The youngest part of the BAR-II\#L column was resampled at a spatial resolution of $0.5 \mathrm{~mm}$ and measured at the IGGR, where the

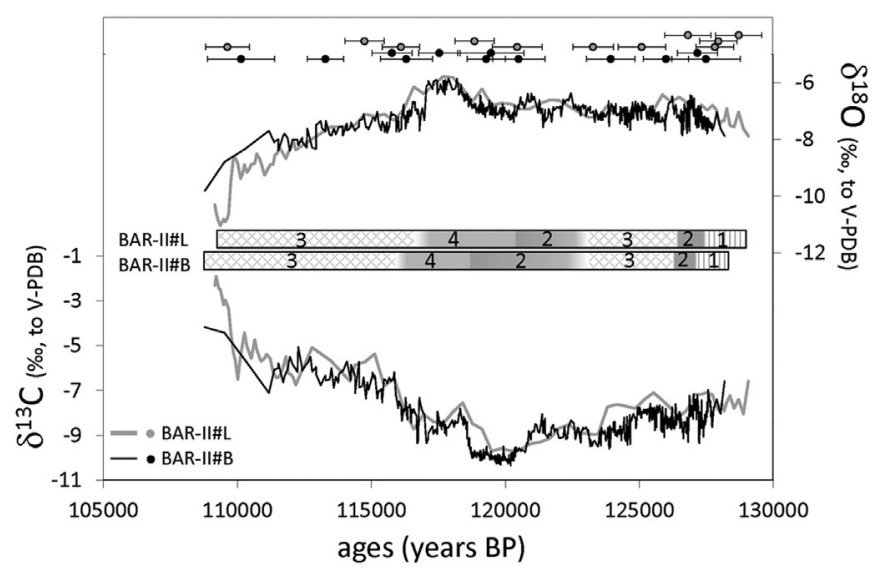

Fig. 4. Stable carbon and oxygen isotope compositions of the two columns (BAR-II\#L and BAR-II\#B) of the BAR-II stalagmite as a function of age. Positions of age dates and their errors are shown in the uppermost panel. Textural types are plotted as a function of age in the middle panel. Texture: \#1: finely laminated texture in which the lamination is expressed by whitish, inclusion-rich layers, \#2: white, cloudy, inclusion-rich texture, \#3: translucent calcite with fine lamination, \#4: pale whitish, cloudy texture with weak lamination. 
BAR-II\#B could be analysed only at low resolution due to earlier sampling for U-Th dating. Both the low and the high-resolution data of the BAR-II\#L column fit the isotopic pattern of the BARII\#B, although there seems to be a systematic $\sim 500$ years shift in the two records. It should be noted, however, that this difference is smaller than the analytical error of the U-Th dating. The $\delta^{13} \mathrm{C}$ values show a larger difference between the two records than the $\delta^{18} \mathrm{O}_{\text {carb }}$ values, but this is in agreement with the stronger kinetic effect on $\mathrm{C}$ isotopes caused by $\mathrm{CO}_{2}$ degassing during carbonate precipitation (Hendy, 1971; Mickler et al., 2004).

The textural types (see section 2) show a correspondence to the isotope data as the inclusion-rich, white layers are associated with low $\delta^{13} \mathrm{C}$ values (Fig. 4). Additionally, the highest water contents are found in the period of 122.1 to $118.6 \mathrm{ka}$ (see Supplementary Table 3), overlapping with the part with the lowest $\delta^{13} \mathrm{C}$ values.

The results of the high-resolution analyses on the BAR-II\#B column are shown in Fig. 4 and listed in Supplementary Table 3. The $\delta^{13} \mathrm{C}$ values range from -10.3 to $-4.2 \%$. The compositions start at a relatively high $\delta^{13} \mathrm{C}$ values of $-6.6 \%$ at $128.2 \mathrm{ka}$ and decrease to about $-10 \%$ with fluctuations. The $\delta^{13} \mathrm{C}$ record has a minimum of around $-10 \%$ in the period of 120.7 to $118.8 \mathrm{ka}$, followed by a sudden increase by about $2 \%$ over 1000 years. After about $118.5 \mathrm{ka}$ the $\delta^{13} \mathrm{C}$ values gradually increase, with a maximum of $-4.2 \%$ at $108.8 \mathrm{ka}$. The $\delta^{18} \mathrm{O}_{\text {carb }}$ values start at about $-8 \%$ at $128.2 \mathrm{ka}$ and show a strong fluctuation of $\sim 1 \%$ and an average $\delta^{18} \mathrm{O}_{\text {carb }}$ value of about $-7 \%$ until $120 \mathrm{ka}$. The $\delta^{18} \mathrm{O}_{\text {carb values start increasing at } 120}$ ka with a steeper increase from $119 \mathrm{ka}$ (contemporaneously with the positive $\delta^{13} \mathrm{C}$ shift), and reach a maximum between 118.4 and $117.1 \mathrm{ka}$, ended with a decrease by $1.2 \%$ at $117 \mathrm{ka}$. Finally the $\delta^{18} \mathrm{O}_{\text {carb }}$ values show a steep decline to $-9.8 \%$ until $108.8 \mathrm{ka}$.

The $\mathrm{H}$ and $\mathrm{O}$ isotope compositions of fluid inclusion water (Supplementary Table 3 ) are positively correlated $\left(R^{2}=0.73\right)$, but some of the $\delta^{18} \mathrm{O}_{\mathrm{w}}$ values are shifted to irrealistically negative values down to $-16.4 \%$. Plotting the $\mathrm{H}$ and $\mathrm{O}$ isotope compositions as a function of age (Fig. 5), similar patterns are obtained for both stalagmite columns and for both isotope compositions. Low $\delta \mathrm{D}$ and $\delta^{18} \mathrm{O}_{\mathrm{w}}$ values characterize the period of 129 to $123 \mathrm{ka}$, high and relatively constant compositions appear between 122 and $119 \mathrm{ka}$, then both the $\delta \mathrm{D}$ and $\delta^{18} \mathrm{O}_{\mathrm{w}}$ values decrease. Evaporation as a cause of the positive $\delta \mathrm{D}-\delta^{18} \mathrm{O}$ correlation is not regarded as a viable process, as in that case the starting compositions (least affected by evaporation) should correspond to the very low $\delta^{18} \mathrm{O}_{\mathrm{w}}$ values that together with the $\delta \mathrm{D}$ values - would mean an irrealistic shift (with a calculated d-excess value of +41 ) from the Global Meteoric Water Line (Craig, 1961). The $\delta^{18} \mathrm{O}_{\mathrm{w}}$ shift to very low values (down to $-16.4 \%$ ) rather indicates that the post-depositional oxygen isotope exchange processes detected by Demény et al. (2016a) affected the BAR-II stalagmite. Demény et al. (2016a) observed coupled changes in $\delta^{18} \mathrm{O}_{\mathrm{w}}$ and calcite crystallinity parameters and related the isotope shift to recrystallization of the stalagmite carbonate and oxygen isotopic re-equilibration between the surrounding calcite and the inclusion-hosted water. As a reason for the re-equilibration they proposed that initially the carbonate was precipitated partly as metastable amorphous calcium carbonate (ACC) that crystallized to calcite after the deposition. On the basis of literature data, they assumed that the ACC-water oxygen isotope fractionation is smaller than the calcite-water fractionation value, hence the $\delta^{18} \mathrm{O}_{\mathrm{w}}$ of the inclusion-hosted water trapped in the ACCcalcite mixture would be shifted to more negative values upon the ACC-calcite transformation. In order to approach the larger calcitewater fractionation, the water composition should change without any appreciable $\delta^{18} \mathrm{O}_{\text {carb }}$ shift due to the mass dominance of the host carbonate. Additionally, Demény et al. (2016c) have found direct mineralogical evidences for ACC precipitation at the cave site and determined the ACC-water oxygen isotope fractionation that
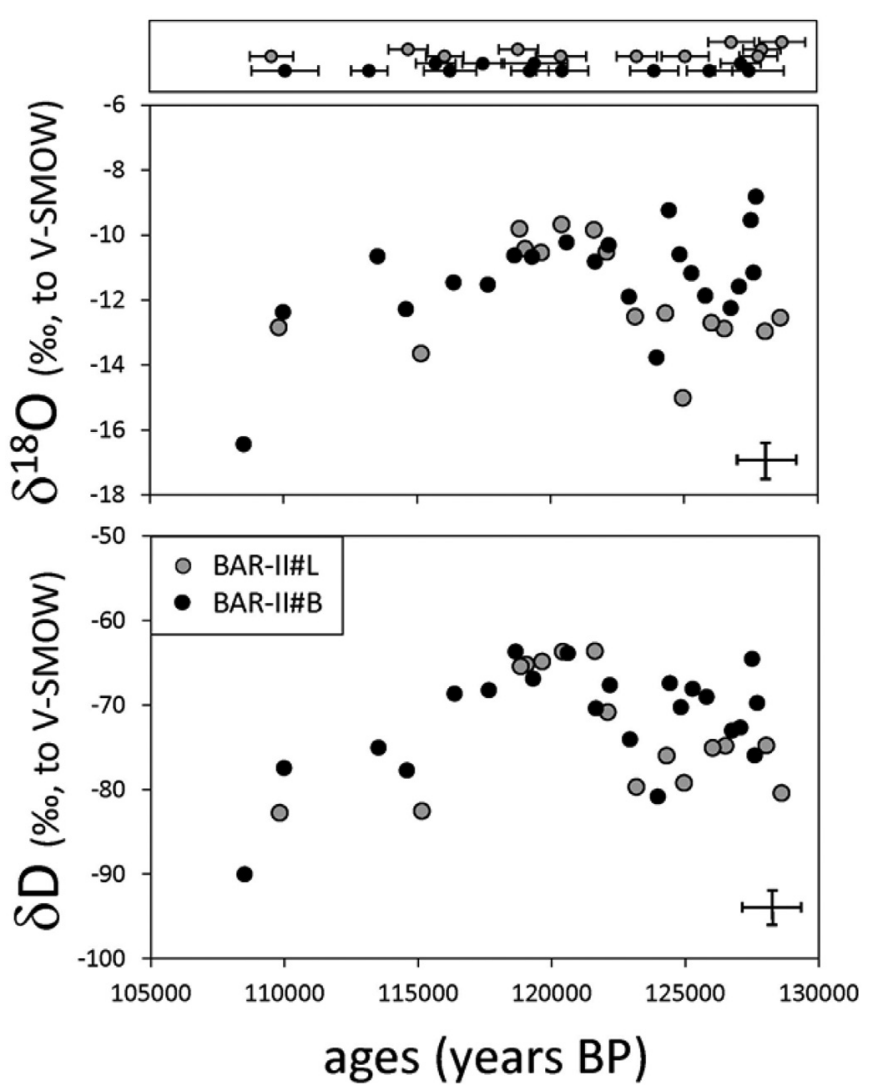

Fig. 5. Stable hydrogen and oxygen isotope compositions of inclusion-hosted water as a function of age. Positions of age dates and their errors are shown in the uppermost panel.

turned out to be at least $2.4 \pm 0.8 \%$ smaller than the calcite-water value, giving support to the assumptions described above. It is interesting to note that the strongest $\delta^{18} \mathrm{O}_{\mathrm{w}}$ shift occurs in the youngest part $(<115 \mathrm{ka}$ ) that belongs to the cooling period of the last interglacial (Govin et al., 2015). Demény et al. (2016a,c) suggested that as ACC is stabilized at low temperature $\left(<10^{\circ} \mathrm{C}\right)$, cooling may induce ACC precipitation at higher proportion, and consequently stronger $\delta^{18} \mathrm{O}_{\mathrm{w}}$ changes, in accordance with the present observation. Hence the $\delta^{18} \mathrm{O}_{\mathrm{w}}$ pattern can be partly related to formation temperatures and may support the primary, climate-related nature of the $\delta \mathrm{D}$ values. However, as the $\delta^{18} \mathrm{O}_{\mathrm{w}}$ values are shifted by the post-depositional processes, only the $\delta \mathrm{D}$ values will be discussed in the followings. As both stalagmite columns provided reliable and comparable age-depth relationships, the $\delta \mathrm{D}$ values will be plotted as a stacked record containing both columns' data.

\section{Discussion}

\subsection{Suitability assessment of the BAR-II stalagmite}

As was demonstrated by Demény et al. (2016b), the carbon and oxygen isotope compositions of the stalagmites grown under interglacial conditions of the Baradla Cave can reflect environmental parameters, but the suitability for paleoclimate analysis of the BAR-II stalagmite should also be investigated, i.e. if the stalagmite's calcite was precipitated under equilibrium conditions. There are two classical tests used to assess equilibrium precipitation: i) the Hendy test (see above), and ii) the comparison of compositions directly measured and calculated from temperature and water composition data. 
As shown in Fig. 3, none of the laminae analysed for Hendy test (Hendy, 1971) showed coupled positive $\delta^{13} \mathrm{C}$ and $\delta^{18} \mathrm{O}_{\text {carb }}$ shifts, hence degassing-related kinetic fractionation was negligible during the formation of the stalagmite. It is important to note that Hendy test analyses on recently forming stalagmites collected close to the sampling location of the BAR-II stalagmite showed no significant $\delta^{18} \mathrm{O}-\delta^{13} \mathrm{C}$ correlations, hence the site can be considered to be free of ventilation-related kinetic fractionation (Demény et al., 2016c).

Another important test for equilibrium is the comparison of measured and calculated compositions. Under conditions of equilibrium the oxygen isotope composition of the calcite is determined by temperature and the water oxygen isotope composition (O'Neil et al., 1969). The main problem is that many equations have been proposed for the calcite-water oxygen isotope fractionation (O'Neil et al., 1969; Friedman and O'Neil, 1977; Kim and O'Neil, 1997; Chacko and Deines, 2008; Coplen, 2007; Horita and Clayton, 2007; Dietzel et al., 2009; Demény et al., 2010; Zheng, 2011; Day and Henderson, 2011; Tremaine et al., 2011; Gabitov et al., 2012); these, however, provided different fractionation values for the same temperature. Two equations were selected as the Devils Hole location fulfils most of the theoretical requirements of equilibrium calcite precipitation (slow precipitation rate, stable environment, Coplen, 2007), while the equation established by Tremaine et al. (2011) is based on a collection of natural cave deposit data selected by avoiding kinetic fractionation bias. The present day temperature of the cave site $\left(9.7 \pm 0.5{ }^{\circ} \mathrm{C}\right)$ and the dripwater composition (see section 2) yield calculated calcite compositions of -7.1 and $-7.6 \%$ for the Coplen (2007) and Tremaine et al. (2011) equations, respectively (with standard deviation of $0.2 \%$ as a result of temperature and water composition variations). The BAR-II $\delta^{18} \mathrm{O}_{\text {carb }}$ values range from -7.7 to $-6.4 \%$ in the fully developed interglacial period (124-120 ka), which range partly overlaps the calculated compositions, suggesting that the BAR-II stalagmite was grown close to equilibrium conditions.

\subsection{Interpretation of stable isotope compositions and variations in climate conditions on the basis of the BAR-II record}

The carbon isotope signal of the Baradla Cave stalagmites can be basically interpreted as a proxy of soil activity depending on temperature and precipitation amount, while the oxygen isotope composition of the carbonate reflects mainly the combined effect of temperature, moisture source and seasonality changes (Demény et al., 2016b). The hydrogen isotope compositions of inclusionhosted water depend on the same factors that determine the drip water compositions and the $\delta^{18} \mathrm{O}_{\text {carb }}$ values, only the effect of carbonate precipitation temperature can be excluded. Hence, the $\delta \mathrm{D}$ and $\delta^{18} \mathrm{O}_{\text {carb }}$ records are expected to have some shared patterns if the environmental parameters change. Temporal variations of $\delta^{13} \mathrm{C}$, $\delta^{18} \mathrm{O}_{\text {carb }}$ and $\delta \mathrm{D}$ records of the BAR-II stalagmite revealed interesting correspondences (Fig. 6).

The BAR-II stalagmite's formation started at around $129 \mathrm{ka}$, indicating that the climate ameliorated at that time to the temperature and humidity conditions appropriate for stalagmite formation at this karstic region. This date corresponds to the starting of maximum interglacial conditions and highest growth rates recorded by stalagmites in Europe (Drysdale et al., 2009; Genty et al., 2013). In the first millennium of the BAR-II stalagmite growth the $\delta^{13} \mathrm{C}$ and $\delta^{18} \mathrm{O}_{\text {carb }}$ values decreased and increased by $\sim 2.5$ and $1.5 \%$, respectively, then they continued the decrease/increase with fluctuations. This suggests that onset of the interglacial conditions was achieved around $128 \mathrm{ka}$, then the interglacial conditions was gradually developing. Climate optimum would mean warm conditions with elevated year-round precipitation amount that is most favorable for soil biogenic activity. Such conditions can

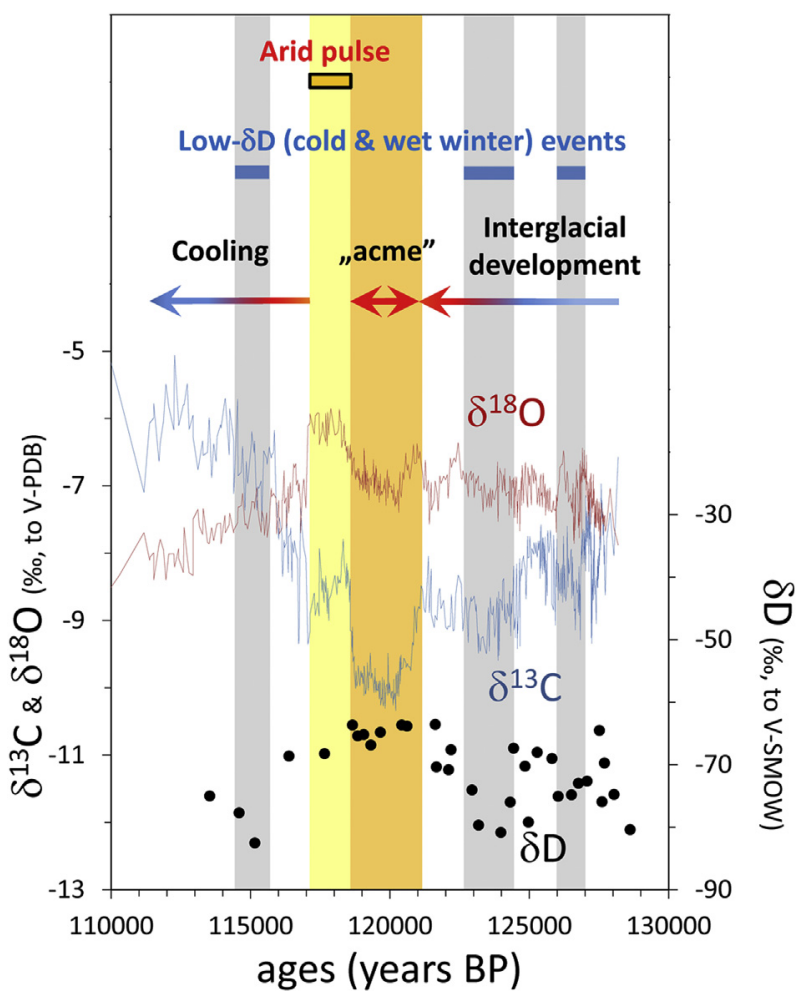

Fig. 6. Combined plot of stable carbon and oxygen isotope compositions of stalagmite carbonate (BAR-II\#B stalagmite column) and hydrogen isotope compositions of inclusion-hosted water. Arrows indicate the periods of interglacial development, ,acme” ( $\delta^{13} \mathrm{C}$ minimum and $\delta^{18} \mathrm{O}_{\text {carb }}$ maximum) and global cooling following Govin et al. (2015). Low $\delta \mathrm{D}$ periods are marked as cold and wet events, while the positive $\delta^{18} \mathrm{O}_{\text {carb }}$ peak is interpreted as an arid period.

be assumed for the period with the lowest $\delta^{13} \mathrm{C}$ (increased soil activity) and elevated $\delta^{18} \mathrm{O}_{\text {carb }}$ and $\delta \mathrm{D}$ values (warm atmospheric temperature). Such compositions are reached in the Baradla Cave's region around $121 \mathrm{ka}$, while the period between 127 and $121 \mathrm{ka}$ can be regarded as the developing phase (Fig. 6). The $\delta$ D values reached their maximum between 121.6 and 118.6 ka overlapping with the period of lowest $\delta^{13} \mathrm{C}$ values (120.7-118.7 ka). Following the nomenclature suggested by Govin et al. (2015), this period can be regarded as the „acme”, meaning climate optimum within the interglacial. In the developing phase the $\delta \mathrm{D}$ values are strongly fluctuating from -65 down to $-81 \%$. The low- $\delta \mathrm{D}$ events are associated with pronounced negative $\delta^{13} \mathrm{C}$ shifts and less expressed negative $\delta^{18} \mathrm{O}_{\text {carb }}$ shifts. These data collectively suggest that these low- $\delta$ D periods were wet (hence the low $\delta^{13} \mathrm{C}$ ) and cold. The reason why the low $\delta \mathrm{D}$ values are not associated with similarly low $\delta{ }^{18} \mathrm{O}_{\text {carb }}$ shifts can be found in the competition of dripwater composition change (driving $\delta^{18} \mathrm{O}_{\text {carb }}$ in negative direction) and formation temperature decrease (driving $\delta^{18} \mathrm{O}_{\text {carb }}$ in positive direction) that effects could partially cancel each other providing a great challenge to environmental interpretation based solely on $\delta^{18} \mathrm{O}_{\text {carb }}$ despite it can be read rather frequently in the speleological literature. The negative $\delta \mathrm{D}$ shift of about $15 \%$ would correspond to about $5{ }^{\circ} \mathrm{C}$ decrease (see temperature calculations below), which is not realistic under full interglacial conditions. Seasonality change such as higher contribution of winter precipitation more depleted in heavy water isotopologues to the infiltrating dripwater (see also Meyer et al., 2008) can explain the observed $\delta D$ shifts. This is elaborated in the paleotemperature calculations described below.

After the developing phase that was punctuated with cold, wet and winter-dominated events, followed by a calm optimum period 
(,acme”, Govin et al., 2015), the $\delta^{13} \mathrm{C}$ values suddenly rose by $2 \%$ at $119 \mathrm{ka}$, indicating a major climate deterioration event. The strong positive $\delta^{13} \mathrm{C}$ shift was coeval with $\delta^{18} \mathrm{O}_{\text {carb }}$ rise, indicating either sudden warming and drying, or seasonality change to summer precipitation dominance. Global cooling had already started before (around $120 \mathrm{ka}$, Govin et al., 2015), hence warming is not expected (although cannot be excluded) in the global cooling phase. Increased aridity during cooling, however, can explain the elevation in $\delta^{13} \mathrm{C}$ and $\delta^{18} \mathrm{O}_{\text {carb }}$ values as it would lead to decreased soil activity and ${ }^{18} \mathrm{O}$-enrichment in water due to evaporation. Reduced humidity can also result in drying of the fractures in the overlying rocks, where the migrating solution may experience carbonate precipitation ("Prior Calcite Precipitation", PCP). Evaporation in the water conduit system and associated PCP can also result in elevated $\delta^{13} \mathrm{C}$ and $\delta^{18} \mathrm{O}$ values in the solution and hence in the precipitating speleothem carbonate (Fairchild and Baker, 2012), contributing to the observed isotope shifts. The $\delta \mathrm{D}$ values remained still close to the „acme” compositions contrary to the effect of global cooling, supporting the assumption of increased aridity as evaporation could also cause D-enrichment in the infiltrating water. It is important to note, that a strong aridity pulse was detected at about $118.5 \mathrm{ka}$ on the basis of greyscale analyses of Eifel maar lake sediments (Sirocko et al., 2005), overlapping the short period of the sudden positive $\delta^{13} \mathrm{C}$ shift. Finally, the isotopic compositions follow the global cooling trend from $117 \mathrm{ka}$ with increasing $\delta^{13} \mathrm{C}$ and decreasing $\delta \mathrm{D}$ and $\delta^{18} \mathrm{O}_{\text {carb values. }}$

Opposite to the carbonate's carbon and oxygen isotope compositions, the advantage of the $\delta \mathrm{D}$ data is that they can be used to infer quantitative formation temperatures, provided that the quantified temperature-composition relation is known for the region's precipitation, and it did not change over time. An approximately three year long sampling campaign (2013-2015) has been conducted at the cave site to determine the $\mathrm{H}$ and $\mathrm{O}$ isotope compositions of precipitation (rain and snow) and their relationships with meteorological conditions (Czuppon et al., in prep.) that yielded a 2.1\%o ${ }^{\circ} \mathrm{C}^{-1}$ gradient for the $\delta \mathrm{D}$ values and surface air temperature (stable $\mathrm{H}$ and $\mathrm{O}$ isotope compositions of the precipitation waters and their relationships with the local air temperature are shown in Supplementary Fig. 1). This gradient can be translated to a $0.488^{\circ} \mathrm{C}$ shift for every $\%$ change in the $\delta \mathrm{D}$ value. Hence, higher $\delta \mathrm{D}$ values compared to the present day dripwater composition would correspond to elevated mean annual temperature at the surface during the last interglacial, and vice versa. The present day gradient may be used for the "acme" (Govin et al., 2015) period, but cooler periods may have been characterized by higher isotope-temperature gradients. The climate conditions of the high-altitude regions of the Alps or the Carpathians north of the Baradla Cave can provide present day analogues where elevated composition-temperature gradients have been reported (Holko et al., 2012; Salamalikis et al., 2016). The hydrogen isotope compositions of precipitation waters can reach a $3.5 \% 0^{\circ} \mathrm{C}^{-1}$ gradient in the Carpathians (Holko et al., 2012) that can be chosen as a cold-climate related gradient value. The present day dripwater composition obtained for the Baradla Cave $(\delta \mathrm{D}=-66 \pm 1.5 \%$ ) can be used as a reference value. First the difference of the measured $\delta \mathrm{D}$ values from this reference composition was calculated, then the $\delta \mathrm{D}$ difference was multiplied by the temperature effect value of $0.488^{\circ} \mathrm{C}_{0}{ }^{-1}$ to obtain the deviation from the present day annual mean temperature. Finally, the temperature deviation value was added to the present day cave site temperature of $9.7^{\circ} \mathrm{C}$ to obtain the annual mean temperature that corresponds to the $\delta \mathrm{D}$ value measured on inclusion-hosted water. The main sources of bias in this calculation are the analytical error of the $\delta \mathrm{D}$ analysis, the uncertainty in temperature-composition gradient and the possible changes in the Local Meteoric Water Line (i.e., the verification of the use of GMWL equation). In order to estimate the uncertainty of temperature values, the calculations were conducted for $\delta \mathrm{D}$-temperature gradients of 2.1 and $3.5 \%{ }^{\circ} \mathrm{C}^{-1}$ and a $2 \%$ error in the $\delta \mathrm{D}$ values. The results are shown in Fig. 7 along with sea surface temperature (SST) data reported by Sánchez-Goñi et al. (2012) for the Bay of Biscay. In order to reduce the noise caused by highfrequency $\delta \mathrm{D}$ variations and sample inhomogeneity effects, the $\delta \mathrm{D}$ values were averaged for every millennium and the average $\delta \mathrm{D}$ values were used in the calculations. The highest temperature obtained in this calculation is $11.2 \pm 1.4{ }^{\circ} \mathrm{C}$ for $120.5 \pm 0.5 \mathrm{ka}$, whereas the lowest temperature value found for $108.5 \mathrm{ka}$ is $3.2 \pm 0.6{ }^{\circ} \mathrm{C}$ (temperatures below zero were excluded as freezing would stop stalagmite formation). The inferred $\sim 8^{\circ} \mathrm{C}$ drop from peak interglacial conditions to the beginning of glacial times is in very good agreement with the independent estimate of mean annual air temperature (MAAT) difference of $10 \pm 2{ }^{\circ} \mathrm{C}$ between the last glacial maximum and present day conditions based on a multiproxy evaluation of regional paleotemperatures in the Pannonian lowlands (Ruszkiczay-Rüdiger and Kern, 2016). Additionally, the calculated paleotemperatures closely follow the pattern of the SST variations of Sánchez-Goñi et al. (2012), indicating that the $\delta D$ values record meaningful paleoclimate information.

This calculation procedure would yield an approximately $5{ }^{\circ} \mathrm{C}$ decrease for the low- $\delta \mathrm{D}$ event at $124 \mathrm{ka}$, which is unrealistic. However, seasonality change can explain the observed D-depletion. Raising the winter precipitation contribution to the infiltrating water would result in decreased dripwater composition. Using $-80 \%$ as a Holocene reference composition that corresponds to the average winter precipitation composition (Czuppon et al., 2016, in prep.), the temperature decrease inferred for the $124 \mathrm{ka}$ peak would totally disappear. This situation is shown by the arrows in Fig. 7 that point to temperature values obtained using the $\delta D_{w}=-80 \%$ reference value in the calculation. Both the $5{ }^{\circ} \mathrm{C}$ temperature decrease and the $100 \%$ winter precipitation contribution represent extreme cases that provide the boundary conditions, a realistic assumption can be characterized by intermediate parameters. These considerations imply that a slight cooling coupled with a rise in winter precipitation contribution to the karstic water can provide an explanation for the low $\delta \mathrm{D}$ values. This speculation can be strengthened if other records showing similar seasonality changes are found. Such paleoclimate records were gathered and compared with the BAR-II record as shown in the following sections.

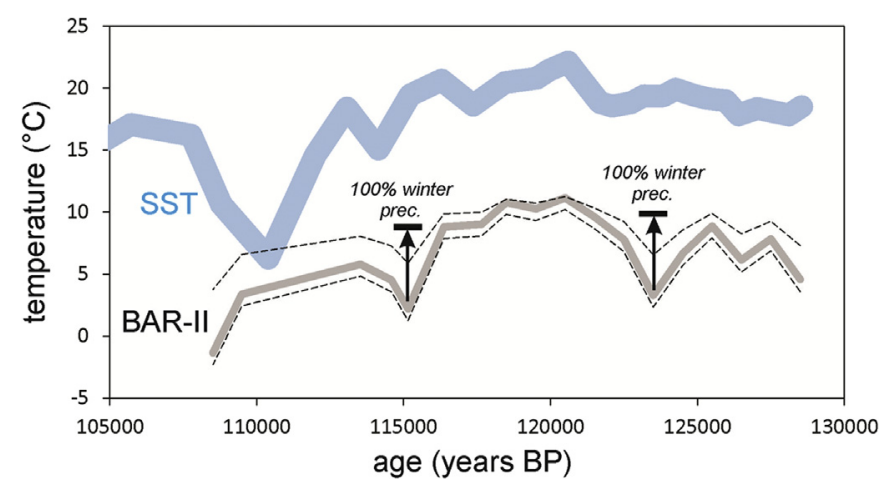

Fig. 7. Paleotemperatures calculated from stable hydrogen isotope compositions (averaged for millennium periods) of fluid inclusion hosted water of the BAR-II stalagmite. Dashed lines indicate the accompanied uncertainty range obtained by error propagation using different isotope-temperature gradients and analytical scatter (see text). Arrows indicate the shift of calculated temperature (marked by horizontal bars) if a reference water hydrogen isotope composition of $-80 \%$ is used in the calculation. Thick blue line shows sea surface temperature (SST) variations reported by SánchezGoñi et al. (2012) for the Bay of Biscay. (For interpretation of the references to colour in this figure legend, the reader is referred to the web version of this article.) 


\subsection{Carbon and oxygen isotope variations - comparisons with LIG speleothems}

Fewer than a dozen speleothem $\mathrm{C}$ and $\mathrm{O}$ isotope records represent at least a part of the LIG in Europe (Linge et al., 2001; Holzkämper et al., 2004; Drysdale et al., 2005; Muñoz-García et al., 2007; Meyer et al., 2008; Couchoud et al., 2009; Boch et al., 2011; Genty et al., 2013; Regattieri et al., 2014; Moseley et al., 2015), and only a few of them cover more than $10 \mathrm{ka}$ including peak interglacial conditions as well as the glacial inception (Drysdale et al., 2005, 2009; Meyer et al., 2008; Moseley et al., 2015; Vansteenberge et al., 2016). In this section the BAR-II data will be compared with eleven stalagmite records from Europe and the Levant (Fig. 8).

Since the formation of the BAR-II stalagmite started after about $129 \mathrm{ka}$, records extending before $130 \mathrm{ka}$ were truncated to keep the focus on their relation to the Baradla records. The paleoclimatic interpretation of isotope records and their comparison depends on the precisions of age determinations of the individual speleothems. On the basis of the speleothem dating precisions (Supplementary Table 4) the chronology of climate variations will be discussed in a ka scale.

The $\delta^{13} \mathrm{C}$ fluctuations (Fig. 9A) show different overall patterns in the stalagmite records, and this is in accordance with earlier conclusions (Meyer et al., 2008; Moseley et al., 2015) concerning the difficulties with the interpretation of the carbon isotope compositions. From 128 to $129 \mathrm{ka}$, the $\delta^{18} \mathrm{O}_{\text {carb }}$ records show a continuous increase, with similar slopes until about 119 ka (Fig. 9B). The stalagmite from the Han-sur-Lesse cave (Belgium, Vansteenberge et al., 2016) represents an exception as its $\delta^{18} \mathrm{O}$ values slightly decrease from 125 ka until about 121 and then rise abruptly at 120 ka. The coupled $\delta^{13} \mathrm{C}-\delta^{18} \mathrm{O}_{\text {carb }}$ patterns suggest that the climate optimum (warm and humid conditions) was attained in the period of $129-119 \mathrm{ka}$, when $\delta^{18} \mathrm{O}_{\text {carb }}$ values were increasing and $\delta^{13} \mathrm{C}$ values were relatively low, indicating a warm and humid climate. This is also valid for the HÖL-10 (Moseley et al., 2015) Alpine stalagmite record, whereas the TKS $\delta^{13} \mathrm{C}$ data (Meyer et al., 2008) display an opposite pattern. The increase in $\delta^{13} \mathrm{C}$ values in the TKS record during the period of $\delta^{13} \mathrm{C}$ minimum in the BAR-II stalagmite indicates humidity differences affecting soil activity and/or kinetic isotope fractionation processes at the two locations.

A marked change in the caves' behavior appeared around $119.5 \pm 0.5 \mathrm{ka}$. The Han-sur-Lesse stalagmite is characterized by a $\delta^{18} \mathrm{O}_{\text {carb }}$ rise of $\sim 0.6 \%$ at about $120 \mathrm{ka}$, which was related to a shift in the moisture source due to the starting growth of polar ice sheets (Vansteenberge et al., 2016). The Entrische cave's TKS record

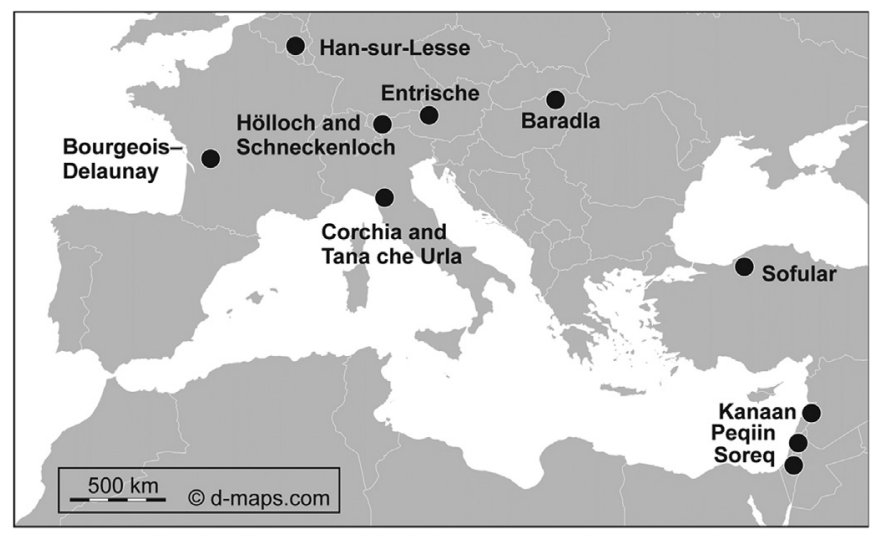

Fig. 8. Locations of caves where stalagmite $\delta^{13} \mathrm{C}$ and $\delta^{18} \mathrm{O}_{\text {carb }}$ records were gathered for the last interglacial. Map is from d-maps.com.
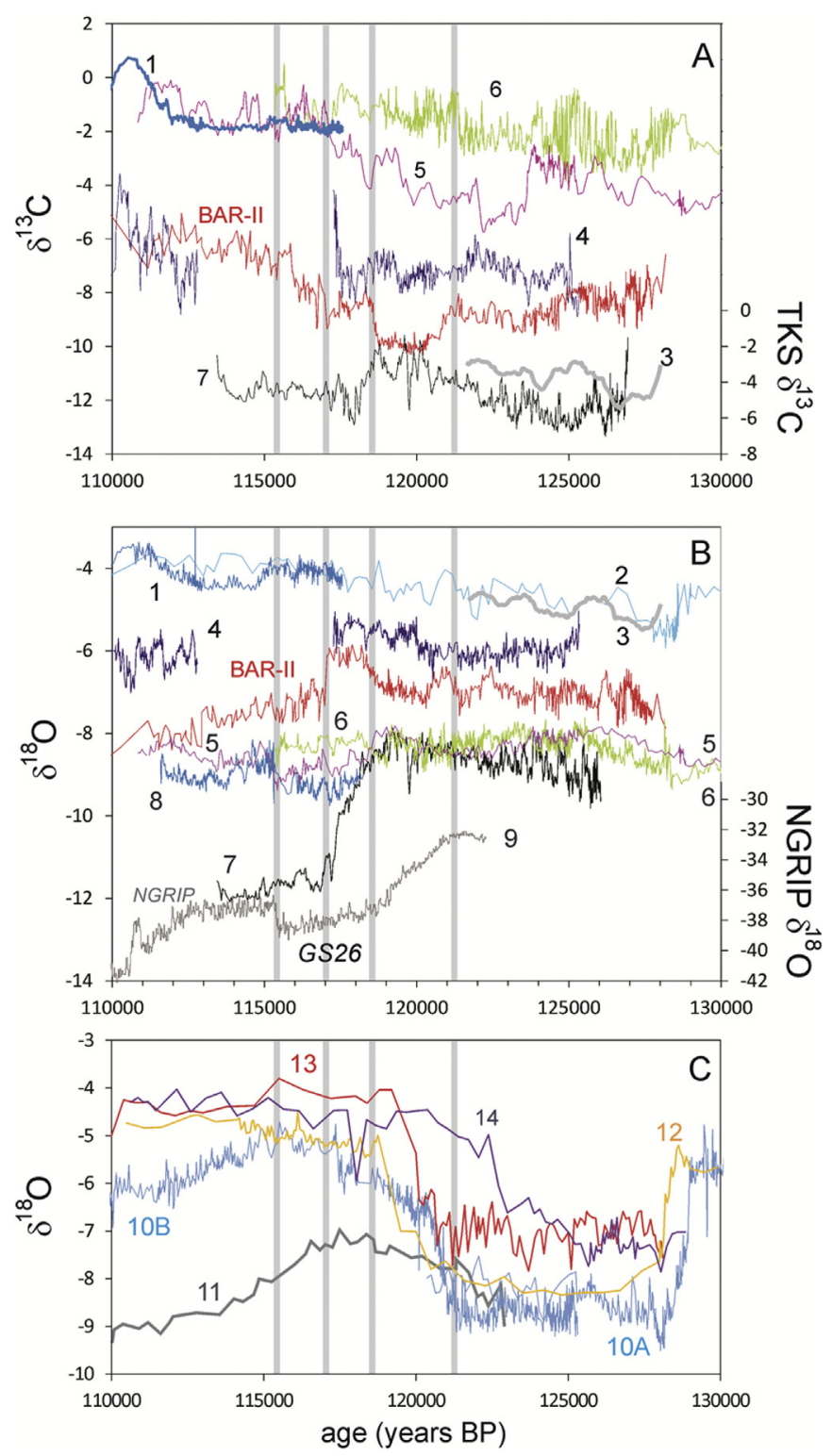

Fig. 9. Stable carbon and oxygen isotope compositions (in\%o relative to V-PDB) of stalagmite and ice core records. BAR-II: this study. 1: Corchia cave, CC28, Drysdale et al. (2007); 2: Corchia Cave, CC5, Drysdale et al. (2005); 3: Bourgeois-Delaunay Cave, Bdinf, Couchoud et al. (2009); 4: Han-sur-Lesse Cave, Han-9, Vansteenberge et al. (2016); 5: Hölloch Cave, HÖL-10, Moseley et al. (2015); 6: Schneckenloch Cave, SCH5, Moseley et al. (2015); 7: Entrische Cave, TKS, Meyer et al. (2008), 8: Schneckenloch Cave, Boch et al. (2011), 9: North Greenland Ice Core Project members (2004) using the GICC05 age scale (Wolff et al., 2010), 10A and 10B: Dongge Cave, Kelly et al. (2006), 11: Sofular Cave, Zumbühl (2010), 12 and 13: Soreq and Peqiin Caves, Bar-Matthews et al. (2003), 14: Kanaan Cave, Nehme et al. (2015). Vertical grey bars mark the onsets and ends of $\delta^{13} \mathrm{C}$ minimum and $\delta^{18} \mathrm{O}$ maximum in the BAR-II stalagmite, and the end of the GS26 event.

(Meyer et al., 2008) shows a decrease in $\delta^{18} \mathrm{O}_{\text {carb }}$ values, which is not reproduced with a comparable amplitude in other Alpine records, although the $\delta^{18} \mathrm{O}_{\text {carb }}$ values slightly decrease in the Schneckenloch and the Hölloch caves' stalagmites (Boch et al., 2011; Moseley et al., 2015). The Corchia $\delta^{18} \mathrm{O}_{\text {carb }}$ records (Drysdale et al., 2005, 2007) show a slight $\delta^{18} \mathrm{O}_{\text {carb }}$ increase between 118 and $115 \mathrm{ka}$ on the top of the continuous ${ }^{18} \mathrm{O}$ enrichment, accompanied by small positive $\delta^{13} \mathrm{C}$ peaks at the same time. With regard to oxygen isotope compositions, the BAR-II stalagmite displays opposite shifts to the Alpine stalagmites after $120 \mathrm{ky}$ (within dating 
uncertainties). The 119-115 ka changes correlate with the Greenland Stadial GS26 in the NGRIP $\delta^{18} \mathrm{O}$ record (North Greenland Ice Core Project members, 2004; using the GICC05 age scale of Wolff et al., 2010) (Fig. 9B). Almost all of the stalagmite isotope records (except the TKS data, Meyer et al., 2008) show positive $\delta^{13} \mathrm{C}$ shifts to different degrees that, taken together with the global cooling reflected by polar ice core data (Fig. 9A and B) indicate soil degradation due to deteriorating environmental conditions. As the North Atlantic Current is suppressed from the north (Müller and Kukla, 2004), less heat and moisture might reach the Alpine cave sites, leading to colder and more arid conditions, hence to lower $\delta^{18} \mathrm{O}$ and higher $\delta^{13} \mathrm{C}$ values in the precipitating carbonate. The strong shift in the Entrische cave's $\delta^{18} \mathrm{O}_{\text {carb }}$ record has been interpreted as a result of changes in seasonality (stronger winter precipitation contribution, Meyer et al., 2008) and/or the fact that the catchment was already affected by glaciation with an increased glacier melt water contribution (Moseley et al., 2015). The GS26 stadial seems to appear in various speleothem records in the territory of the Asian monsoon (Kelly et al., 2006), in the Levant (BarMatthews et al., 2003) and on the Black Sea coast (Zumbühl, 2010) (Fig. 9C). These records indicate lower rainfall amount during the GS26 stadial. It is interesting to note that the BAR-II $\delta^{18} \mathrm{O}_{\text {carb }}$ record indicates a strongly arid pulse in the same period that points again to the decisive connection between the Mediterranean moisture availability and the Carpathian Regions's hydroclimate. The period of elevated $\delta^{18} \mathrm{O}$ values ends with a decrease at about $117 \mathrm{ka}$ that occurred contemporaneously with the growth stop of the Han-surLesse stalagmite (Vansteenberge et al., 2016) and the steep $\delta^{18} \mathrm{O}$ decrease in the TKS record (Meyer et al., 2008), suggesting different responses in the regional temperature and humidity changes in Western and Central Europe to the large-scale event triggering the GS26 cooling at Greenland.

With the exception of the TKS stalagmite, all the records display a concerted change at the end of the GS26 stadial, at $116 \mathrm{ka}$ (Fig. 9A-C). This abrupt change may be related to an approximately $5{ }^{\circ} \mathrm{C}$ warming in Greenland (Kindler et al., 2014), which can be detected in small positive $\delta^{18} \mathrm{O}_{\text {carb }}$ peaks in the BAR-II and the Schneckenloch and the Hölloch caves' records (Boch et al., 2011; Moseley et al., 2015). This peak is, however, negligible compared to the sudden $\delta^{18} \mathrm{O}_{\text {carb }}$ decrease in the BAR-II stalagmite at $117 \mathrm{ka}$ coupled with a rise in $\delta^{13} \mathrm{C}$. This may reflect the appearance of Atlantic moisture in the region of the Baradla Cave, and hence the BAR-II $\delta^{18} \mathrm{O}_{\text {carb }}$ pattern returns to the long-term global trend. Finally, the BAR-II record follows the global cooling that lead to glacial inception and stalagmite formation ceased at about $108 \mathrm{ka}$. Due to the more elevated position, the Alpine sites would be more sensitive to glaciation, thus stalagmite formation ceased about $1 \mathrm{ka}$ earlier (Fig. 9B), although it might result from dating uncertainty, too.

\subsection{The hydrogen isotope record - global and regional relationships}

The pattern of hydrogen isotope compositions of fluid inclusion hosted water is similar to the records representing regional and global climate conditions (Fig. 10) such as the Greenland ice core $\delta{ }^{18} \mathrm{O}$ data (North Greenland Ice Core Project members, 2004; using the GICC05 age scale of Wolff et al., 2010) and selected stable isotope compositions and sea surface temperature reconstructions derived from North Atlantic deep sea sediment cores (Bauch et al., 2011; Sánchez-Goñi et al., 2012; Galaasen et al., 2014). It should be noted here that dating of deep sea records is a challenging task (e.g., Drysdale et al., 2009), and the North Atlantic region may behave heterogeneously with respect to temperature anomalies during climate change events (Capron et al., 2014) that must be kept in

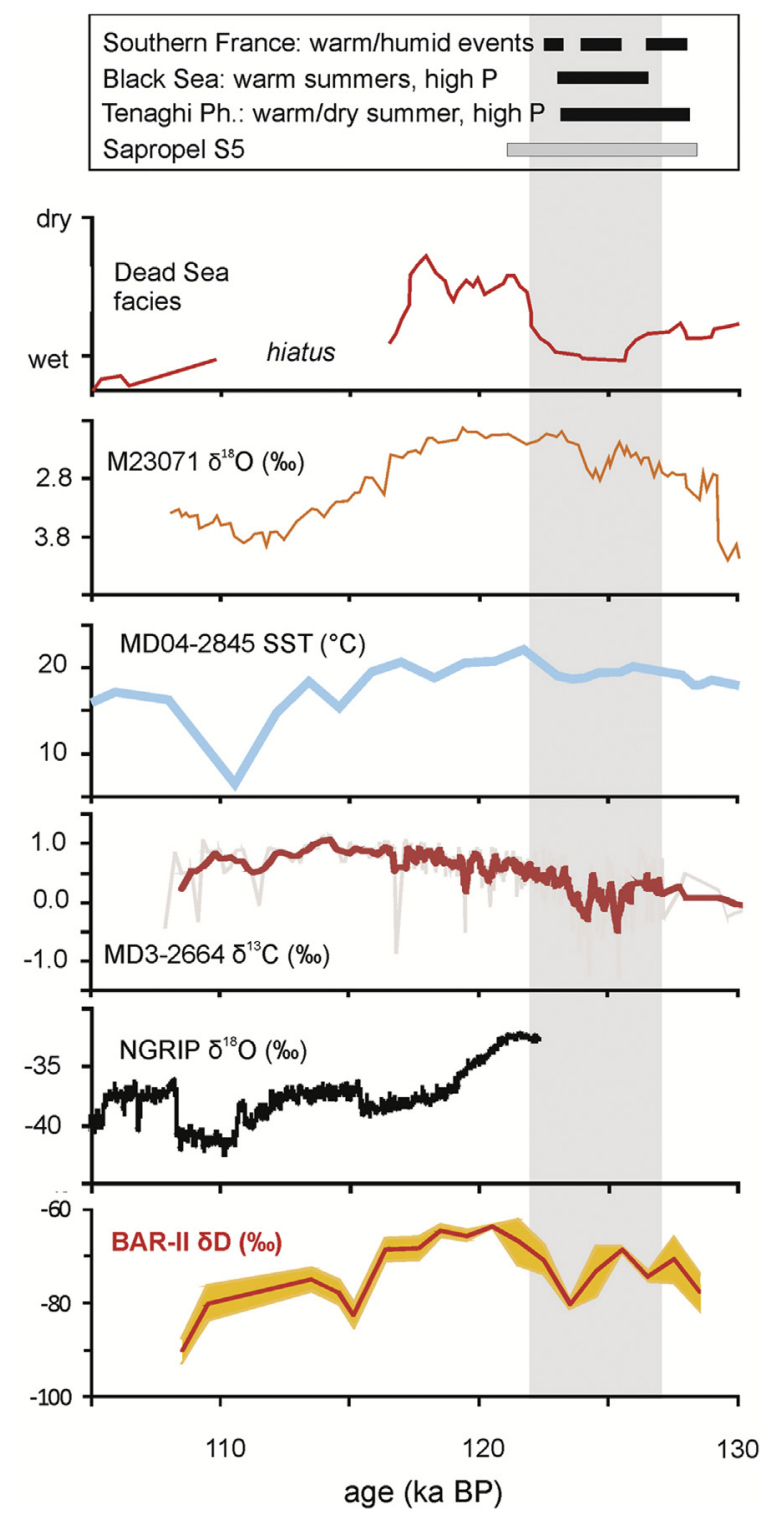

Fig. 10. Stable hydrogen isotope compositions of inclusion-hosted water from the BARII stalagmite (lowermost panel) and various proxy records from the Atlantic and Mediterranean regions. The BAR-II $\delta \mathrm{D}$ values are millennial averages. NGRIP: North Greenland Ice Core Project members (2004), using the GICC05 age scale (Wolff et al., 2010). MD3-2664 $\delta^{13} \mathrm{C}$ : North Atlantic drilling site, south of Greenland, Galaasen et al. (2014). MD04-2845 SST: Biscay Bay, Sánchez-Goñi et al. (2012). M23071 $\delta^{18} 0$ : Norwegian Sea, Bauch et al. (2011). Dead Sea sedimentary facies distribution: Torfstein et al. (2015). Sapropel S5: Grant et al. (2012). Tenaghi Philippon: Milner et al. (2012). Black Sea: Shumilovskikh et al. (2013). Southern France: Couchoud et al. (2009).

mind during the evaluation. The selected records demonstrate that the period of low $\delta \mathrm{D}$ values in the BAR-II record was associated with climate changes in the wider region. Nevertheless, the good match with these records and the rather complex relationships in the $\mathrm{C}-\mathrm{O}$ isotope data of speleothems may suggest that the $\delta \mathrm{D}$ record is less influenced by local, cave-related effects compared to the C-O isotope values.

One of the most prominent features in the $\delta \mathrm{D}$ pattern is the low $\delta \mathrm{D}$ peaks detected between 127 and $123 \mathrm{ka}$. The very large $\delta \mathrm{D}$ changes (up to $17 \%$ within 2.5 ka, see Fig. 5) during an interglacial period are unusual and require additional evidence that prove their primary nature (not related to the alteration processes or analytical procedure). First it should be noted that the low $\delta \mathrm{D}$ values were 
obtained in different analytical runs and from two stalagmite columns that reduces the chance of analytical bias. Second, the low $\delta \mathrm{D}$ values are associated with decreased $\delta^{13} \mathrm{C}$ values in the BAR-II stalagmite (Fig. 6) that excludes the possibility of procedurerelated isotope shifts. As discussed above, low $\delta^{13} \mathrm{C}$ values indicate increased humidity, and the same (with relative increase of winter precipitation) is assumed for the low $\delta \mathrm{D}$ values (see above). Regional humidity proxies are provided for the period by the carbon isotope compositions of the Han-9 stalagmite (Han-sur-Lesse Cave, Vansteenberge et al., 2016) and the BDinf stalagmite (Bourgeois-Delaunay Cave, Couchoud et al., 2009) that can serve as independent test records. Fig. 11 shows a comparison of these records, indicating that the low $\delta \mathrm{D}$ values in the BAR-II stalagmite are indeed associated with low $\delta^{13} \mathrm{C}$ values and higher humidity in the period of 127-123 ka. The magnitude of the $\delta \mathrm{D}$ fluctuation is related to local fractionation processes, but the timing and directions of isotope shifts can be correlated in a regional scale.

The low $\delta \mathrm{D}$ period fits several paleoclimate records from the Mediterranean to the North Atlantic regions (Fig. 10). At the same time the Dead Sea had elevated water levels (Torfstein et al., 2015), in agreement with the humid climate inferred for the eastern Mediterranean and increased Nile floods, leading to the formation of sapropel S5 (Grant et al., 2012). For the period of 128 to $123 \mathrm{ka}$ Milner et al. (2012) have suggested pronounced seasonality with increased summer aridity and winter precipitation on the basis of acicular aragonite formation (indicating enhanced evaporation) in an otherwise aquatic phase of the Tenaghi Philippon peatland (NE Greece). The inferred precipitation seasonality is in agreement with the assumptions of increased winter precipitation around the Baradla Cave based on paleotemperature calculations (see section 5.2.). On the basis of pollen data from a Black Sea sediment core, Shumilovskikh et al. (2013) have also come to the same conclusion, assuming warm summers and mild winters with increased annual precipitation for the period of 126.4 to $122.9 \mathrm{ka}$. In a sediment core from the Western Mediterranean Sea, n-alkane based temperature estimates showed a maximum at about $125 \mathrm{ka}$ (Kandiano et al., 2014), suggesting that the humid period was accompanied with a warm event in this area. In the $\mathrm{C}$ and $\mathrm{O}$ isotope data from a stalagmite from Southern France, Couchoud et al. (2009) detected fluctuations of warm/wet and cold/dry periods, with increased

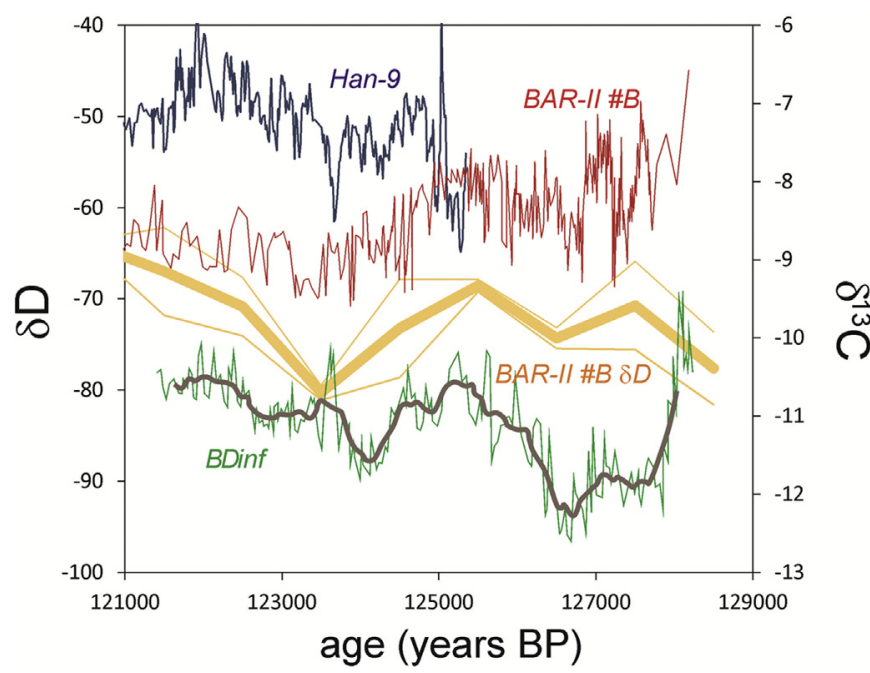

Fig. 11. Millennial averages of fluid inclusion $\delta \mathrm{D}$ values (in \%o relative to V-SMOW, with $1 \sigma$ standard deviations shown by thin lines) and $\delta^{13} \mathrm{C}$ records (in \%o relative to V-PDB) of the Han-9 (Vansteenberge et al., 2016), the BDinf (Couchoud et al., 2009) and the BAR-II (this study) stalagmites. rainfall amount at $127.9-126.3,125.3-123.8$ and $123.1-122.4 \mathrm{ka}$, as shown also in Fig. 11. In summary, South European proxy data indicate that the 128-123 ka period represented by these records was characterized by warm conditions (especially during summer) and elevated annual precipitation.

Beside the Mediterranean data, several North Atlantic deep-sea isotope records from further afield display interesting similarities to the BAR-II $\delta \mathrm{D}$ pattern. As also shown in Fig. 10, stable isotope peaks obtained for planctonic foraminifers at 125-124 ka appear in several North Atlantic deep sea cores around Greenland (Bauch et al., 2011; Van Nieuwenhove et al., 2011; Irvalı et al., 2012; Galaasen et al., 2014), and may be interpreted as a result of a Younger Dryas type event (Bauch, 2013). The event is generally explained as resulting from a freshwater influx from melting ice sheets that induced a reduction in the Atlantic Meridional Overturning Circulation (AMOC) and associated cooling in the northernmost parts of the Atlantic realm. However, the event was not homogeneous in the entire North Atlantic as shown by the temperature anomaly distributions compiled by Capron et al. (2014).

In contrast to the Mediterranean data, certain European paleoclimate proxies indicate cooling and precipitation changes during the early-mid LIG. As shown in Fig. 11 in detail, the precisely (better than \pm 700 years) dated $\delta^{13} \mathrm{C}$ record of a stalagmite from the Hansur-Lesse cave (Belgium) indicates humidity fluctuations during the period of 128 to $121 \mathrm{ka}$ (Vansteenberge et al., 2016). Slight temperature decrease at about 126 and 122 ka has been detected in a sea surface temperature record at the Bay of Biscay by SánchezGoñi et al. (2012) that fit the low- $\delta$ D peaks (Fig. 10) within dating uncertainties.

In order to investigate the spatial differences in climate conditions, proxy information gathered from those records that detected a climate change event at about 126-122 ka at a sufficient resolution ( $200 \mathrm{yr} / \mathrm{sample})$ to resolve this event, were plotted on a map (Fig. 12).

The spatial distribution confirms the impression that most of the European continent was characterized by elevated humidity, while the temperature conditions were different with significant warming in the Mediterranean. A new climate model simulation for the last interglacial period of the Atlantic-Mediterranean region was conducted including freshwater flux to the northernmost Atlantic Ocean (Stone et al., 2016). Interestingly, the simulation

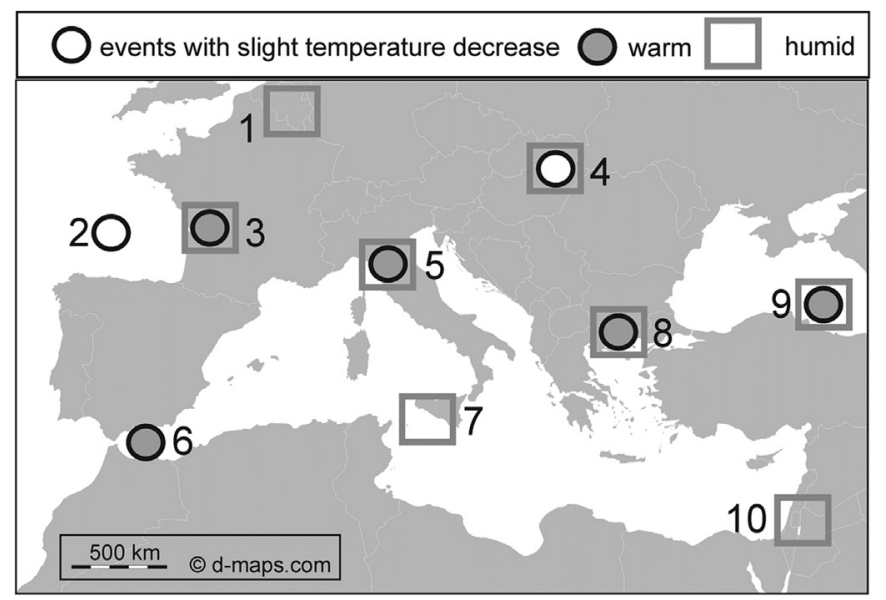

Fig. 12. Temperature and humidity information in last interglacial proxy records between 126 and 122 ka. 1: Vansteenberge et al. (2016). 2: Sánchez-Goñi et al. (2012). 3: Couchoud et al. (2009). 4: BAR-II (this study). 5: Drysdale et al. (2007) and Regattieri et al. (2014). 6: Kandiano et al. (2014). 7: Censi et al. (2010). 8: Milner et al. (2012). 9: Shumilovskikh et al. (2013). 10: Torfstein et al. (2015). 
experiment resulted in a similar picture (see Fig. 7 of Stone et al., 2016) to that shown in Fig. 12, suggesting that freshwater flux to the Northern Atlantic changed moisture and heat transport trajectories.

\section{Synthesis and conclusions}

Stable carbon and oxygen isotope compositions of carbonate, and hydrogen and oxygen isotope compositions of inclusion-hosted water were obtained for a stalagmite covering a large part of the last interglacial (129-109 ka) from the Baradla Cave (NE Hungary). The stable isotope records were correlated with various coeval regional proxy and paleoclimate records, including stable isotope data of speleothems, ice cores, deep sea cores, and sea surface temperature values. The comparison revealed a series of events that characterized the complex climate evolution of the European continent and the eastern Mediterranean.

The climate reached full interglacial conditions at the Baradla Cave at about $128 \mathrm{ka}$, when the BAR-II stalagmite formation commenced. The $\mathrm{C}$ and $\mathrm{O}$ isotope compositions indicate an approach to the climate optimum that was attained around $124 \mathrm{ka}$ and lasted until about $120 \mathrm{ka}$. However, the BAR-II $\delta \mathrm{D}$ pattern displays negative $\delta \mathrm{D}$ peaks between 127 and $123 \mathrm{ka}$, which is associated with negative $\delta^{13} \mathrm{C}$ shifts, but not reflected in the $\delta^{18} \mathrm{O}_{\text {carb }}$ values, probably due to competing fractionation effects. The low $\delta \mathrm{D}$ period can be correlated with climate change events detected in paleoclimate records ranging from $\delta^{18} \mathrm{O}$ and SST records from deep sea cores from the North Atlantic to paleobiological and sedimentological records from marine and continental sediments from Western Europe to the Eastern Mediterranean. Paleotemperature and -moisture information was gathered from proxy records of Western and Central Europe and the Mediterranean region that cover the period of interest with appropriate age constraints and resolution. A systematic spatial pattern was revealed with overall increased humidity from NW to SE, and significant warming in the Mediterranean. Stable isotope records of several North Atlantic deep sea cores and climate simulations suggest that the humidity and temperature changes are related to freshwater influx from melting ice sheets at about $125 \mathrm{ka}$ (e.g., Bauch, 2013; Stone et al., 2016), with this perturbation being responsible for shifting heat and moisture transport towards the Mediterranean. The event is also associated with increased humidity and seasonality (elevated winter/summer precipitation ratio) in East-Central Europe as documented at the Baradla Cave in accordance with observations from the eastern Mediterranean and the Black Sea region.

After the climate optimum between 124 and $120 \mathrm{ka}$ (the Baradla Cave „acme”, Govin et al., 2015), global cooling processes induced changes in the Western-Central European and Mediterranean regions. Strong cooling started in the Alps at about $119 \mathrm{ka}$, while the Baradla $\delta^{13} \mathrm{C}$ values are the lowest and the $\delta \mathrm{D}$ record shows a maximum, suggesting increased summer precipitation in still favorable temperature conditions for soil activity. These mild conditions ended at $118 \mathrm{ka}$, when the Alpine stalagmite records indicate a strong cooling in concert with the onset of the Greenland stadial GS26. In the course of the Greenland stadial GS26 the North Atlantic Current was shifted to the south, resulting in cooler and drier conditions, while the Baradla Cave experienced stronger evaporation effects. These conditions changed as reflected by sharp $\delta^{13} \mathrm{C}$ and $\delta^{18} \mathrm{O}$ shifts in the BAR-II record at $117 \mathrm{ka}$, still within the GS26 event. The sudden negative $\delta^{18} \mathrm{O}$ shift at $117 \mathrm{ka}$ in the BAR-II stalagmite likely indicates the appearance of Atlantic moisture and the effect of global cooling. The GS26 event ended with a sudden warming, that appears as slight $\delta^{18} \mathrm{O}$ shifts in the Alpine stalagmites and in the Corchia and the Baradla caves. Finally, global cooling was reflected by continuous negative shifts in the BAR-II $\delta^{18} \mathrm{O}_{\text {carb }}$ and $\delta \mathrm{D}$ values until the glacial inception at $109 \mathrm{ka}$.

The complex set of climate change events can be related to the north-south movements of the North Atlantic Current combined with global temperature trends. Although $\mathrm{C}$ and $\mathrm{O}$ isotope compositions reflected most of the events and proved their synchronicity, the competing fractionation effects may partially attenuate the climate signal in speleothem proxy records. The BAR-II $\delta \mathrm{D}$ record not only helped interpret the seasonality signal in the $\delta^{13} \mathrm{C}$ $\delta^{18} \mathrm{O}_{\text {carb }}$ record, but was also successfully used to detect a significant mid-interglacial climate event at $125 \mathrm{ka}$.

\section{Acknowledgements}

We would like to express our gratitude to three anonymous reviewers whose suggestions helped clarify our ideas. This research was supported by the National Office for Research and Technology of Hungary (GVOP-3.2.1-2004-04-0235/3.0), the Hungarian Scientific Research Fund (OTKA CK 80661 and OTKA NK 101664) and the "Momentum-Lendület" program of the Hungarian Academy of Sciences (LP2012-27/2012). The Bolyai János research scholarship received by György Czuppon greatly helped his work. U-Th dating was supported by Taiwan ROC MOST and NTU grants (103-2119-M002-022, 104-2119-M-002-003 and 101R7625). This is contribution No. 41 of the 2ka Palaeoclimatology Research Group.

\section{Appendix A. Supplementary data}

Supplementary data related to this article can be found at http:// dx.doi.org/10.1016/j.quascirev.2017.02.012.

\section{References}

Affolter, S., Fleitmann, D., Leuenberger, M., 2014. New online method for water isotope analysis of speleothem fluid inclusions using laser absorption spectroscopy (WS-CRDS). Clim. Past 10, 1291-1304.

Arienzo, M.M., Swart, P.K., Vonhof, H.B., 2013. Measurement of $\delta^{18} \mathrm{O}$ and $\delta^{2} \mathrm{H}$ values of fluid inclusion water in speleothems using cavity ring-down spectroscopy compared with isotope ratio mass spectrometry. Rapid Commun. Mass Spectrom. 27, 2616-2624.

Ayalon, A., Bar-Matthews, M., Frumkin, A., Matthews, A., 2013. Last glacial warm events on Mount Hermon: the southern extension of the Alpine karst range of the east Mediterranean. Quat. Sci. Rev. 59, 43-56.

Bar-Matthews, M., Ayalon, A., Gilmour, M., Matthews, A., Hawkesworth, C., 2003 Sea-land oxygen isotopic relationships from planktonic foraminifera and speleothems in the Eastern Mediterranean region and their implication for paleorainfall during interglacial intervals. Geochim. Cosmochim. Acta 67 3181-3199.

Bartholy, J., Pongrácz, R., Pattantyús-Ábrahám, M., 2006. European cyclone track analysis based on ECMWF ERA-40 data sets. Int. J. Climatol. 26, 1517-1527.

Bartholy, J., Pongrácz, R., Pattantyús-Ábrahám, M., 2009. Analyzing the genesis intensity, and tracks of western Mediterranean cyclones. Theor. Appl. Climatol. 96, 133-144.

Bauch, H.A., 2013. Interglacial climates and the Atlantic meridional overturning circulation: is there an Arctic controversy? Quat. Sci. Rev. 63, 1-22.

Bauch, H.A., Kandiano, E.S., Helmke, J.P., Andersen, N., Rosell-Mele, A Erlenkeuser, H., 2011. Climatic bisection of the last interglacial warm period in the Polar North Atlantic. Quat. Sci. Rev. 30, 1813-1818.

Boch, R., Cheng, H., Spötl, C., Edwards, R.L., Wang, X., Häuselmann, P., 2011. NALPS: a precisely dated European climate record 120-60 ka. Clim. Past 7, 1247-1259.

Bottyán, E., Czuppon, G., Weidinger, T., Haszpra, L., Kármán, K., 2013. Determination of air moisture source region for precipitation in Hungary. Cent. Eur. Geol. 56 273.

Capron, E., Govin, A., Stone, E.J., Masson-Delmotte, V., Mulitza, S., Otto-Bliesner, B., Rasmussen, T.L., Sime, L.C., Waelbroeck, C., Wolff, E.W., 2014. Temporal and spatial structure of multi-millennial temperature changes at high latitudes during the Last Interglacial. Quat. Sci. Rev. 103, 116-133.

Censi, P., Incarbona, A., Oliveri, E., Bonomo, S., Tranchida, G., 2010. Yttrium and REE signature recognized in Central Mediterranean Sea (ODP site 963) during the MIS 6-MIS 5 transition. Palaeogeogr. Palaeoclimatol. Palaeoecol. 292, 201-210.

Chacko, T., Deines, P., 2008. Theoretical calculation of oxygen isotopic fractionation factors in carbonate systems. Geochim. Cosmochim. Acta 72, 3642-3660.

Cheng, H., Edwards, R.L., Sinha, A., Spötl, C., Yi, L., Chen, S., Kelly, M., Kathayat, G. Wang, X., Li, X., Kong, X., Wang, Y., Ning, Y., Zhang, H., 2016. The Asian monsoon over the past 640,000 years and ice age terminations. Nature 534, 640-646.

Coplen, T.B., 2007. Calibration of the calcite-water oxygen-isotope geothermometer 
at Devils Hole, Nevada, a natural laboratory. Geochim. Cosmochim. Acta 71, 3948-3957.

Couchoud, I., Genty, D., Hoffmann, D.L., Drysdale, R., Blamart, D., 2009. Millennialscale climate variability during the Last Interglacial recorded in a speleothem from South-western France. Quat. Sci. Rev. 28, 3263-3274.

Craig, H., 1961. Isotopic variations in meteoric waters. Science 133, 1702-1703.

Czuppon, Gy., Demény, A., Leél-Őssy, Sz., Óvari, M., Molnár, M., Stieber, J., Kármán K., Kiss, K., Haszpra., L., Cave monitoring in Béke and Baradla Caves (NE Hungary): implications for the condition of the formation of cave carbonates (in prep.).

Czuppon, Gy, Ramsay, R.R., Özgenc, I., Demény, A., Gwalani, L.G., Rogers, K., Eves, A. Papp, L., Palcsu, L., Berkesi, M., Downes, P.J., 2014. Stable (H, O, C) and noble-gas (He and $\mathrm{Ar}$ ) isotopic compositions from calcite and fluorite in the Speewah Dome, Kimberley Region, Western Australia: implications for the conditions of crystallization and evidence for the influence of crustal-mantle fluid mixing. Mineral. Petrol. 108, 759-775.

Day, C.C., Henderson, G.M., 2011. Oxygen isotopes in calcite grown under caveanalogue conditions. Geochim. Cosmochim. Acta 75, 3956-3972.

Demény, A., Kele, S., Siklósy, Z., 2010. Empirical equations for the temperature dependence of calcite-water oxygen isotope fractionation from 10 to $70{ }^{\circ} \mathrm{C}$ Rapid Commun. Mass Spectrom. 24, 3521-3526.

Demény, A., Czuppon, Gy, Kern, Z., Leél-Őssy, Sz, Németh, A., Szabó, M., Tóth, M. Wu, Ch-Ch., Shen, Ch-Ch., Molnár, M., Németh, T., Németh, P., Ovári, M., 2016a. Recrystallization-induced oxygen isotope changes in inclusion-hosted water of speleothems - paleoclimatological implications. Quat. Int. 415, 25-32.

Demény, A., Németh, A., Kern, Z., Czuppon, Gy, Molnár, M., Leél-Őssy, Sz, Óvári, M. Stieber, J., 2016b. Recently forming stalagmites from the Baradla Cave and their suitability assessment for climate-proxy relationships. Cent. Eur. Geol. (in press).

Demény, A., Németh, P., Czuppon, Gy, Leél-Őssy, Sz, Szabó, M., Judik, K., Németh, T. Stieber, J. 2016c. Formation of amorphous calcium carbonate in caves and its implications for speleothem research. Sci. Rep. Sci. Rep. 6:39602.

Dietzel, M., Tang, J., Leis, A., Köhler, S., 2009. Stable isotopic fractionation during inorganic calcite precipitation - effects of temperature, precipitation rate and pH. Chem. Geol. 268, 107-115.

Dorale, J.A., Liu, Z., 2009. Limitations of Hendy test criteria in judging the paleoclimatic suitability of speleothems and the need for replication. J. Cave Karst Stud. 71, 73-80.

Drysdale, R.N., Zanchetta, G., Hellstrom, J.C., Fallick, A.E., Zhao, J., 2005. Stalagmite evidence for the onset of the Last Interglacial in southern Europe at $129 \pm 1 \mathrm{ka}$. Geophys. Res. Lett. 32, L24708.

Drysdale, R.N., Zanchetta, G., Hellstrom, J.C., Fallick, A.E., McDonald, J., Cartwright, I, 2007. Stalagmite evidence for the precise timing of North Atlantic cold events during the early last glacial. Geology 35, 77-80.

Drysdale, R.N., Hellstrom, J.C., Zanchetta, G., Fallick, A.E., Sánchez-Goñi, M.F. Couchoud, I., McDonald, J., Maas, R., Lohmann, G., Isola, I., 2009. Evidence for obliquity forcing of glacial termination II. Science 325, 1527-1531.

Dublyansky, Y., Spötl, C., 2009. Hydrogen and oxygen isotopes of water from inclusions in minerals: design of a new crushing system and on-line CF-IRMS analysis. Rapid Commun. Mass Spectrom. 23, 2605-2613.

EPICA community members, 2004. Eight glacial cycles from an Antarctic ice core. Nature 429, 623-628.

Fairchild, I.J., Baker, A., 2012. Speleothem Science. Wiley-Blackwell, p. 450.

Friedman, I., O'Neil, J.R., 1977. Compilation of Stable Isotope Fractionation Factors of Geochemical Interest. Data of Geochemistry. U.S. Geological Survey, Professional Paper 440-KK.

Gabitov, R.I., Watson, E.B., Sadekov, A., 2012. Oxygen isotope fractionation between calcite and fluid as a function of growth rate and temperature: an in situ study. Chem. Geol. 306-307, 92-102.

Galaasen, E.V., Ninnemann, Ulysses S., Irvalı, U.S., Kleiven, N., Rosenthal, H., C, Y. Kissel, Hodell, D.A., 2014. Rapid reductions in North Atlantic deep water during the peak of the last interglacial period. Science 343, 1129-1132.

Genty, D., Verheyden, S., Wainer, K., 2013. Speleothem records over the last interglacial. PAGES News 21, 24-25.

Govin, A., Capron, E., Tzedakis, P.C., Verheyden, S., Ghaleb, B., Hillaire-Marcel, C. StOnge, G., Stoner, J.S., Bassinot, F., Bazin, L., Blunier, T., Combourieu Nebout, N., E Quahabi, A., Genty, D., Gersonde, R., Jiminez-Amat, P., Landais, A., Martrat, B. Masson-Delmotte, V., Parrenin, F., Seidenkrantz, M.S., Veres, D., Waelbroeck, C. Zahn, R., 2015. Sequence of events from the onset to the demise of the Last Interglacial: evaluating strengths and limitations of chronologies used in climatic archives. Quat. Sci. Rev. 129, 1-36.

Grant, K.M., Rohling, E.J., Bar-Matthews, M., Ayalon, A., Medina-Elizalde, M., Bronk Ramsay, C., Satow, C., Roberts, A.P., 2012. Rapid coupling between ice volume and polar temperature over the past 150,000 years. Nature 491, 744-747.

Griffiths, M.L., Drysdale, R.N., Vonhof, H.B., Gagan, M.K., Zhao, J.X., Ayliffe, L.K. Hantoro, W.S., Hellstrom, J.C., Cartwright, I., Frisia, S., Suwargadi, B.W., 2010. Younger Dryas-Holocene temperature and rainfall history of southern Indonesia from $\delta 180$ in speleothem calcite and fluid inclusions. Earth Planet. Sci. Lett. 295, 30-36.

Harmon, R.S., Schwarcz, H.P., 1981. Changes in ${ }^{2} \mathrm{H}$ and ${ }^{18} \mathrm{O}$ enrichment of meteoric water and Pleistocene glaciations. Nature 290, 125-128.

Hendy, C.H., 1971. The isotopic geochemistry of speleothems-I: the calculations of the effects of different modes of formation on the isotopic composition of speleothems and their applicability as paleoclimate indicators. Geochim. Cosmochim. Acta 35, 801-824.
Holko, L., Dóša, M., Michalko, J., Šanda, M., 2012. Isotopes of oxygen-18 and deuterium in precipitation in Slovakia. J. Hydrol. Hydromech. 60, 265-276.

Holzkämper, S., Mangini, A., Spötl, C., Mudelsee, M., 2004. Timing and progression of the last Interglacial derived from a high Alpine stalagmite. Geophys. Res. Lett. 31, L07201.

Horita, J., Clayton, R.N., 2007. Comment on the studies of oxygen isotope fractionation between calcium carbonates and water at low temperatures by Zhou and Zheng (2003; 2005). Geochim. Cosmochim. Acta 71, 3131-3135.

Irvalı, N., Ninnemann, U.S., Galaasen, E.V., Rosenthal, Y., Kroon, D., Oppo, D.W., Kleiven, H.F., Darling, K.F., Kissel, C., 2012. Rapid switches in subpolar North Atlantic hydrography and climate during the Last Interglacial (MIS 5e). Paleoceanography 27. PA 2207.

Kandiano, E.S., Bauch, H.A., Fahl, K., 2014. Last interglacial surface water structure in the western Mediterranean (Balearic) Sea: climatic variability and link between low and high latitudes. Glob. Planet. Change 123, 67-76.

Kelemen, F.D., Bartholy, J., Pongrácz, R., 2015. Multivariable cyclone analysis in the Mediterranean region. Időjárás - Q. J. Hung. Meteorol. Serv. 119, 159-184.

Kelly, M.J., Edwards, R.L., Cheng, H., Yuan, D., Cai, Y., Zhang, M., Lin, Y., An, Z., 2006. High resolution characterization of the Asian Monsoon between 146,000 and 99,000 years BP from Dongge Cave, China and global correlation of events surrounding Termination II. Palaeogeogr. Palaeoclimatol. Palaeoecol. 236, $20-38$.

Kim, S.-T., O'Neil, J.R., 1997. Equilibrium and nonequilibrium oxygen isotope effects in synthetic carbonates. Geochim. Cosmochim. Acta 61, 3461-3475.

Kindler, P., Guillevic, M., Baumgartner, M., Schwander, J., Landais, A., Leuenberger, M., 2014. Temperature reconstruction from 10 to 120 kyr b2k from the NGRIP ice core. Clim. Past 10, 887-902.

Linge, H., Lauritzen, S.E., Lundberg, J., 2001. Stable isotope stratigraphy of a late last interglacial speleothem from Rana, northern Norway. Quat. Res. 56, 155-164.

Lisiecki, L.E., Raymo, M.E., 2005. A Pliocene-Pleistocene stack of 57 globally distributed benthic $\delta^{18} \mathrm{O}$ records. Paleoceanography 20, PA1003.

Loutre, M.F., Berger, A., 2003. Marine Isotope Stage 11 as an analogue for the present interglacial. Glob. Planet. Change 36, 209-217.

Meyer, M.C., Spötl, C., Mangini, A., 2008. The demise of the Last Interglacial recorded in isotopically dated speleothems from the Alps. Quat. Sci. Rev. 27, 476-496.

Mickler, P.J., Banner, J.L., Stern, L.A., Asmerom, Y., Edwards, R.L., Ito, E., 2004. Stable isotope variations in modern tropical speleothems: evaluating equilibrium vs. kinetic isotope effects. Geochim. Cosmochim. Acta 68, 4381-4393.

Milner, A.M., Collier, R.E.L., Roucoux, K.H., Müller, U.C., Pross, J., Kalaitzidis, S., Christanis, K., Tzedakis, P.C., 2012. Enhanced seasonality of precipitation in the Mediterranean during the early part of the Last Interglacial. Geology 40, 919-922.

Moseley, G.E., Spötl, C., Cheng, H., Boch, R., Min, A., Edwards, R.L., 2015. Termination-II interstadial/stadial climate change recorded in two stalagmites from the north European Alps. Quat. Sci. Rev. 127, 229-239.

Mudelsee, M., Fohlmeister, J., Scholz, D., 2012. Effects of dating errors on nonparametric trend analyses of speleothem time series. Clim. Past 8, 1637-1648.

Muñoz-García, M.B., Martín-Chivelet, J., Rossi, C., Ford, D.C., Schwarcz, H.P., 2007. Chronology of Termination II and the Last Interglacial Period in North Spain based on stable isotope records of stalagmites from Cueva del Cobre (Palencia). J. Iber. Geol. 33, 17-30.

Müller, U.C., Kukla, G.J., 2004. North Atlantic Current and European environments during the declining stage of the last interglacial. Geology 32, 1009-1012.

Nehme, C., Verheyden, S., Noble, S.R., Farrant, A.R., Sahy, D., Hellstrom, J. Delannoy, J.J., Claeys, P., 2015. Reconstruction of MIS 5 climate in the central Levant using a stalagmite from Kanaan Cave. Lebanon. Clim. Past 11, 1785-1799.

North Greenland Ice Core Project members, 2004. High-resolution record of Northern Hemisphere climate extending into the last interglacial period. Nature 431, 147-151.

O'Neil, J.R., Clayton, R., Mayeda, T., 1969. Oxygen isotopic fractionation in divalent metal carbonates. J. Chem. Phys. 51, 5547-5558.

Regattieri, E., Zanchetta, G., Drysdale, R.N., Isola, I., Hellstrom, J.C., Roncioni, A., 2014. A continuous stable isotope record from the penultimate glacial maximum to the Last Interglacial (159-121 ka) from Tana Che Urla Cave (Apuan Alps, central Italy). Quat. Res. 82, 450-461.

Rowe, P.J., Mason, J.E., Andrews, J.E., Marca, A.D., Thomas, L., van Calsteren, P., Jex, C.N., Vonhof, H.B., Al-Omari, S., 2012. Speleothem isotopic evidence of winter rainfall variability in northeast Turkey between 77 and 6ka. Quat. Sci. Rev. 45, 60-72.

Ruszkiczay-Rüdiger, Zs, Kern, Z., 2016. Permafrost or seasonal frost? A review of paleoclimate proxies of the last glacial cycle in the East Central European lowlands. Quat. Int. 415, 241-252.

Salamalikis, V., Argiriou, V.V., Dotsika, E., 2016. Periodicity analysis of $\delta^{18} \mathrm{O}$ in precipitation over Central Europe: time-frequency considerations of the isotopic 'temperature' effect. J. Hydrol. 534, 150-163.

Sánchez-Goñi, M.F., Bakker, P., Desprat, S., Carlson, A.E., Van Meerbeeck, C., Peyron, O., Naughton, F., Fletcher, W.J., Eynaud, F., Rossignol, L., Renssen, H., 2012. European climate optimum and enhanced Greenland melt during the Last Interglacial. Geology 40, 627-630.

Scholz, D., Hoffmann, D.L., 2011. StalAge - an algorithm especially designed for construction of speleothem age. Quat. Geochronol. 6, 369-382.

Shen, C.-C., Edwards, R.L., Cheng, H., Dorale, J.A., Thomas, R.B., Moran, S.B., Weinstein, S.E., Hirschmann, M., 2002. Uranium and thorium isotopic and concentration measurements by magnetic sector inductively coupled plasma 
mass spectrometry. Chem. Geol. 185, 165-178.

Shen, C.-C., Cheng, H. Edwards, R.L., Moran, S.B., Edmonds, H.N., Hoff, J.A. Thomas, R.B., 2003. Measurement of attogram quantities of 231Pa in dissolved and particulate fractions of seawater by isotope dilution thermal ionization mass spectroscopy. Anal. Chem. 75, 1075-1079.

Shen, C.-C., Wu, C.-C., Cheng, H., Edwards, R.L., Hsieh, Y.-T., Gallet, S., Chang, C.-C. Li, T.-Y., Lam, D.D., Kano, A., Hori, M., Spötl, C., 2012. High-precision and highresolution carbonate ${ }^{230} \mathrm{Th}$ dating by MC-ICP-MS with SEM protocols. Geochim. Cosmochim. Acta 99, 71-86.

Shumilovskikh, L.S., Arz, H.W., Wegwerth, A., Fleitmann, D., Marret, F, Nowaczyk, N., Tarasov, P., Behling, H., 2013. Vegetation and environmental changes in Northern Anatolia between 134 and 119 ka recorded in Black Sea sediments. Quat. Res. 80, 349-360.

Sirocko, F., Seelos, K., Schaber, K., Rein, B., Dreher, F., Diehl, M., Lèhne, R., Jäger, K., Krbetschek, M., Degering, D., 2005. A Late Eemian Aridity Pulse in central Europe during the last glacial inception. Nature 436, 833-836.

Spötl, C., Vennemann, T.W., 2003. Continuous-flow IRMS analysis of carbonate minerals. Rapid Commun. Mass Spectrom. 17, 1004-1006.

Stone, E.J., Capron, E., Lunt, D.J., Payne, A.J., Singarayer, J.S., Valdes, P.J., Wolff, E.W., 2016. Impact of meltwater on high-latitude early Last Interglacial climate. Climate of the Past 12, 1919-1932.

Szalai, S., Auer, I., Hiebl, J., Milkovich, J., Radim, T., Stepanek, P., Zahradnicek, P., Bihari, Z., Lakatos, M., Szentimrey, T., Limanowka, D., Kilar, P., Cheval, S. Deak, Gy, Mihic, D., Antolovic, I., Mihajlovic, V., Nejedlik, P., Stastny, P., Mikulova, K., Nabyvanets, I., Skyryk, O., Krakovskaya, S., Vogt, J., Antofie, T., Spinoni, J., 2013. Climate of the Greater Carpathian Region. Final Technical Report. www.carpatclim-eu.org.

Torfstein, A., Goldstein, S.L., Kushnir, Y., Enzel, Y., Haug, G., Stein, M., 2015. Dead Sea drawdown and monsoonal impacts in the Levant during the last interglacial. Earth Planet. Sci. Lett. 412, 235-244.
Tremaine, D.M., Froelich, P.N., Wang, Y., 2011. Speleothem calcite farmed in situ: Modern calibration of $\delta^{18} \mathrm{O}$ and $\delta^{13} \mathrm{C}$ paleoclimate proxies in a continuouslymonitored natural cave system. Geochim. Cosmochim. Acta 75, 4929-4950.

van Breukelen, M.R., Vonhof, H.B., Hellstrom, J.C., Wester, W.C.G., Kroon, D., 2008 Fossil dripwater in stalagmites reveals Holocene temperature and rainfall variation in Amazonia. Earth Planet. Sci. Lett. 275, 54-60.

Van Nieuwenhove, N., Bauch, H.A., Eynaud, F., Kandiano, E., Cortijo, E., Turon, J.-L., 2011. Evidence for delayed poleward expansion of North Atlantic surface waters during the last interglacial (MIS 5e). Quat. Sci. Rev. 30, 934-946.

Vansteenberge, S., Verheyden, S., Cheng, H., Edwards, R.L., Keppens, E., Claeys, P. 2016. Paleoclimate in continental northwestern Europe during the Eemian and early Weichselian (125-97 ka): insights from a Belgian speleothem. Clim. Past $12,1445-1458$.

Vonhof, H.B., van Breukelen, M.R., Postma, O., Rowe, P.J., Atkinson, T.C., Kroon, D. 2006. A continuous-flow crushing device for on-line $\delta^{2} \mathrm{H}$ analysis of fluid inclusion water in speleothems. Rapid Commun. Mass Spectrom. 20, 2553-2558.

Wainer, K., Genty, D., Blamart, D., Daëron, M., Bar-Matthews, M., Vonhof, H. Dublyansky, Y., Pons-Branchu, E., Thomas, L., van Calsteren, P., Quinif, Y., Caillon, N., 2011. Speleothem record of the last $180 \mathrm{ka}$ in Villars cave (SW France): Investigation of a large $\delta^{18} \mathrm{O}$ shift between MIS6 and MIS5. Quat. Sci. Rev. 30, 130-146.

Wolff, E.W., Chappellaz, J., Blunier, T., Rasmussen, S.O., Svensson, A., 2010. Millennial-scale variability during the last glacial: The ice core record. Quat. Sci. Rev. 29, 2828-2838.

Yonge, C.J., 1982. Stable Isotope Studies of Water Extracted from Speleothems. PhD thesis. McMaster University, Hamilton, ON, Canada, p. 270.

Zheng, Y.-F., 2011. On the theoretical calculations of oxygen isotope fractionation factors for carbonate-water systems. Geochem. J. 45, 341-354.

Zumbühl, A., 2010. History of the Black Sea Recorded in Stalagmites from Northern Turkey. Master's Thesis. University of Bern, p. 114. 